\title{
Eksperyment somatyczno-dramaturgiczny. Haptyczna wizualność i deziluzyjna dramaturgia w filmie Czarny Łabędź Darrena Aronofsky'ego
}

\begin{abstract}
Adrianna Woroch, Eksperyment somatyczno-dramaturgiczny. Haptyczna wizualność i deziluzyjna dramaturgia w filmie Czarny Łabędź Darrena Aronofsky'ego [A somatic-dramaturgic experiment. Haptic visuality and self-reflexive dramaturgy in Darren Aronofsky's Black Swan]. „Przestrzenie Teorii" 36. Poznań 2021, Adam Mickiewicz University Press, pp. 219-228. ISSN 1644-6763. DOI 10.14746/pt.2021.36.13.

Based on the example of Darren Aronofsky's film Black Swan, the article explores the disillusive potential of interfering with the classic model of film dramaturgy. Referring to the traditional paradigm developed by Syd Field, the author indicates deviations from the conventional narrative that occur in Aronofsky's film. The text seeks to confirm the thesis that contemporary cinematography exemplifies the trend of abandoning the attempts to create a seemingly referential world. By questioning the fundamental structure of the film's dramaturgy, Black Swan provides additional interpretive possibilities. However, displaying the constituent elements of a work, for example, by transaccentuating their meaning or changing their place or length of occurrence, is not the most obvious disillusionment strategy. It may in fact remain hidden until the moment of careful analysis.
\end{abstract}

KEYWORDS: Black Swan, Syd Field's dramaturgy paradigm, disillusionment, haptic visuality, sensuous theory

\section{Kino a referencyjność - kilka słów wstępu}

W kinematografii ostatnich czterech dekad wyraźnym trendem stało się odchodzenie od pozorów referencyjności. Film - niegdyś sztuka uważana za związaną u podstaw z kreowaniem iluzji - od kilku dziesięcioleci wyzwala się spod tych narzuconych odgórnie zasad. Zrywa więzy nakładane nań przez teoretyków aż do przełomu lat pięćdziesiątych i sześćdziesiątych. Początki teorii X muzy przebiegały bowiem pod znakiem rozważania relacji kina i rzeczywistości. Starano się wówczas wskazać cel nowego medium w odniesieniu do jego technicznych możliwości reprodukcji otaczającego świata. Na czele takiego nurtu myślowego stał francuski krytyk André Bazin, współzałożyciel najsłynniejszego czasopisma w historii kinematografii - „Cahiers du Cinéma”. W wypracowanej przez Bazina ontologii punktami wyjścia są sztuka i religia egipska, która uzależniała nieśmiertelność duszy od materialnego stanu ciała. To dążenie do ochrony przed czasem badacz uznaje za jedną z najważniej- 
szych psychologicznych potrzeb ludzkich. Bezpośrednio z niej wywodzi się z kolei ambicja zastapienia świata zewnętrznego jego nieśmiertelnym sobowtórem. Sztuka pozwoliła tę obsesję zaspokoić, utrwalając od zarania dziejów wizerunki osób, miejsc i przedmiotów, a zatem jednocześnie ochraniając je przed śmiercia. Film - w opinii Bazina - potrafi to zadanie spełnić lepiej od innych mediów dzięki swoim technicznym predyspozycjom. Ma dzięki nim możliwość ukazywania odległych światów, niedostępnych dla statystycznego widza stanów zmysłowych bądź zdarzeń, których nie dałoby się zauważyć gołym okiem (choćby procesów natury, zbyt wolnych lub zbyt szybkich, by mogły zostać zarejestrowane przez niedoskonałą ludzką percepcję).

Wspierane przez Bazina i jego kontynuatorów dążenie do kina w formie maksymalnie mechanicznej reprodukcji świata zewnętrznego, wykluczającej subiektywną wizję twórcy i zakładającej, że wszelka dramaturgia powinna wynikać bezpośrednio z rzeczywistości, a nie z manipulacji montażowej, wydaje się mocno naiwnym manifestem. Teoretyk, funkcjonujący w towarzystwie francuskich nowofalowców, głosił niewątpliwie tezy archaiczne nawet jak na tamte czasy, a z dzisiejszej perspektywy już zupełnie nietrafione. Trudno sobie bowiem wyobrazić kino pozbawione artystycznej wizji i określonego stylu. Co więcej, współczesne filmy stawiają nierzadko czynny opór teoriom propagującym kino „stylu zerowego”, a więc z jasno zarysowaną fabuła, prowadzona zgodnie z linearną narracją i przedstawiająca wycinek świata, który ma kreować wrażenie referencyjności. Takie opowieści, roszczące sobie prawo do postrzegania ich jako przekazujących jakaśs obiektywną Prawdę (w znaczeniu zakwestionowanym przez postmodernistów), stały się punktami odniesienia dla współczesnych dzieł deziluzyjnych. To właśnie na przekór w ten sposób budowanej iluzji dzieła takie jak Synekdocha, Nowy Jork (reż. Charlie Kaufman, 2008), Holy Motors (reż. Leos Carax, 2012) czy Być jak John Malkovich (reż. Spike Jonze, 1999) konstruują własne interpretacje narracji i jej podstawowych struktur, w tym - logiki, dramaturgii, postaci narratora czy sposobu przeprowadzenia samego aktu opowiadania.

Spośród wymienionych powyżej aspektów dramaturgia jest zagadnieniem szczególnie w mojej opinii interesujacym, a zarazem stosunkowo często pomijanym w tekstach teoretycznofilmowych traktujących o nowych formach współczesnych dzieł. Zdaje się bowiem być traktowana jako pewna oczywistość, w konsekwencji czego bagatelizuje się jej kreacyjny potencjał w kształtowaniu tendencji kina, pochylającego się w ostatnich czterech dekadach w stronę deziluzyjności i porzucania tradycyjnego mimetyzmu. Współcześnie naiwnością jest już zatem traktowanie dzieła jako sekwencji elementów niejako naturalnie z siebie wynikających. Co za tym idzie, należy również porzucić perspektywę Bazinowska, proklamująca, by dramaturgię w filmie tworzyć w sposób właśnie „naturalny” (co paradoksalnie wiąże się 
z oparciem jej na wyliczonych zasadach, skostniałych w ramach konwencji kina klasycznego).

Przedmiotem niniejszych rozważań będzie specyficzny eksperyment z dramaturgia, którego podją się amerykański reżyser Darren Aronofsky w filmie Czarny Łabędź. Jest to egzemplifikacja znacznie rozleglejszej tendencji w kinie współczesnym. Film eksploruje klasyczny model narracyjny poprzez wprowadzenie do niego wariacji, lecz w zamian oferuje alternatywne - oparte na afektach i haptycznej wizualności - sposoby budowania napięcia dramaturgicznego.

\section{Klasyczny schemat dramaturgiczny}

Jak już zostało wspomniane, jedną z najważniejszych struktur niezaprzeczalnie obecnych w kinie czy wręcz je konstytuujaccych jest dramaturgia, brana nadal za pewną oczywistość. Nie trzeba bowiem nikogo przekonywać, że film bez dramaturgii tudzież $\mathrm{z}$ nieudolnie ulokowana dramaturgią to z pewnością film zły. Warto jednak zauważyć, że nierzadko w kinie współczesnym struktura dramaturgiczna celowo odbiega od zasad podręcznikowych i staje się wówczas mechanizmem deziluzyjnym. Odbiorca spodziewa się bowiem, że poszczególne elementy - wprowadzenie, moment kulminacyjny czy zakończenie - będa sukcesywnie następować po sobie, w odpowiednich odstępach czasowych i w odpowiedniej konwencjonalnej, z góry przyjętej formie. Kiedy tak się nie dzieje, widz zostaje wytrącony z biernego, zaprogramowanego odbioru i przełącza się na inny - bardziej świadomy. I dzieje się tak, mimo że mogłoby się wydawać, iż odejście od zasad struktury dramaturgicznej będzie dla filmu jednoznaczne z katastrofa. Inaczej bowiem niż porzucenie ciagłości miejsca i czasu, a czasami nawet logiki przyczynowo-skutkowej ${ }^{1}$, dramaturgia z pozoru nadal wydaje się warunkiem sine qua non. Film powinien stosować się, przynajmniej po części, do ogólnie przyjętych zasad prowadzenia historii. W przeciwnym razie realizatorów czeka spektakularne fiasko, a widzów - kolejna po The Room (reż. Tommy Wiseau, 2003), Zabójczych ryjówkach (reż. Ray Kellogg, 1959) czy Planie dziewięć z kosmosu (reż. Ed Wood, 1959) legenda kina klasy Z. Dowodem na wciąż żywe przekonanie o konieczności podążania za wytycznymi w zakresie konstrukcji scenariusza są - nadal chętnie czytane przez adeptów sztuki filmowej - sztandarowe dzieła z dziedziny scenariopisarstwa, tworzone zresztą w duchu bardzo strukturalistycznym. Zakładają

${ }^{1} \mathrm{Na}$ przykład w przypadku dzieł awangardowych, efemerycznych, a więc mających dać widzowi odczuć nieuchwytny nastrój, tempo czy też wprowadzić go w pewien określony stan ducha i umysłu. 
one (z pewnością ku uciesze Władimira Proppa), że zdarzenia w filmie powinny wynikać jedne z drugich, a przestawienie poszczególnych morfemów ${ }^{2}$ nie może prowadzić do stworzenia spójnej fabuły (jak wyżej).

Zgodnie z najpopularniejszym paradygmatem dramaturgii filmowej, opracowanym przez Syda Fielda i Rolfa Rillę w książce Pisanie scenariusza filmowego ${ }^{3}$, dzieło ma charakteryzować się tradycyjną trzyaktową struktura, w ramach której każda część ma określone proporcje i powinna następować w konkretnym punkcie filmu, a także trwać tylko - oraz dokładnie - tak długo, aż nie nastapi naturalne (a raczej - ściśle wyliczone, z naturalnością niemające zbyt wiele wspólnego) przejście do kolejnego etapu.

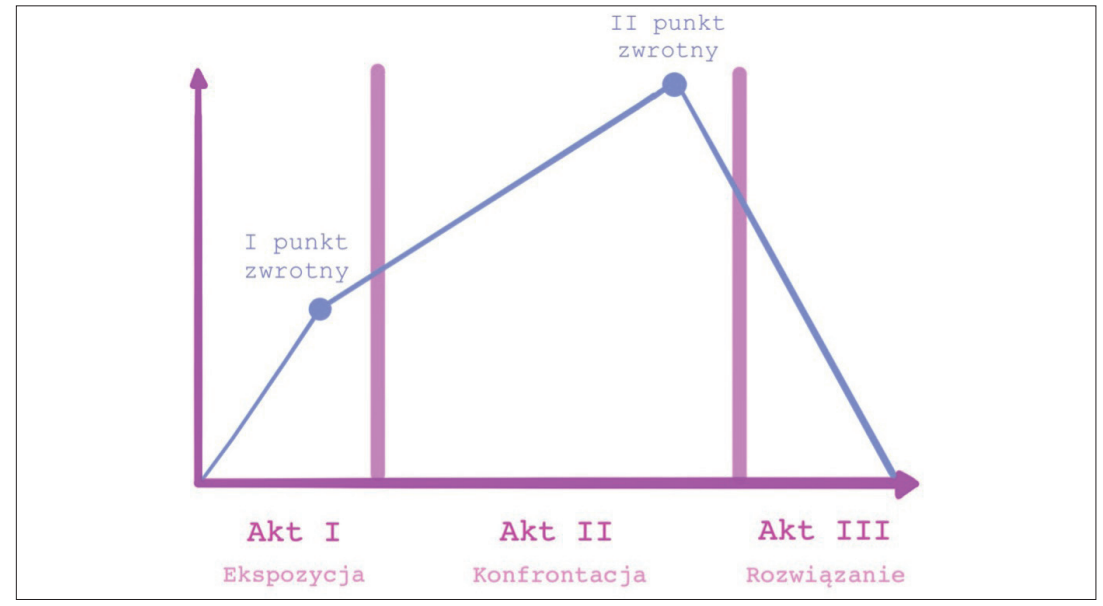

Schemat dramaturgiczny filmu opracowany przez Syda Fielda.

Akt pierwszy - a więc około trzydziestu minut filmu - odgrywa rolę wstępu, ekspozycji. Określa czas i miejsce akcji, wprowadza bohaterów oraz zarysowuje konflikt. Ponadto chwilę przed końcem aktu pierwszego powinien nastapić punkt zwrotny, wokół którego powinna toczyć się dalsza część filmu.

W końcowej fazie aktu pierwszego następuje pewien rodzaj przesilenia dramaturgicznego, tzw. punkt zwrotny, czyli zgodnie z wykładnią klasycznej poetyki Arystotelesa - „perypetia”, pojmowana jako „zmiana losów w szczęście lub nieszczęście". Innymi słowy, punkt zwrotny, w tym przypadku pierwszy punkt zwrotny, to zdarzenie, które zasadniczo zmienia tok akcji, kieruje ją w nowa, nieoczekiwaną stronę, niekiedy nawet całkowicie odwraca jej bieg. Bywa to przeważnie - jak za-

${ }^{2}$ Nawiązuję tu do nomenklatury, którą stosował Propp w odniesieniu do opisanych funkcji, elementów bajki. Zob. V. Propp, Morfologia bajki magicznej, przeł. P. Rojek, Kraków 2011.

${ }^{3}$ S. Field, R. Rilla, Pisanie scenariusza filmowego, przeł. W. Wertenstein, B. Pankau, Warszawa 1998. 
uważa Maciej Karpiński - odkrycie jakiejś nowej, wcześniej nie - przewidywalnej prawdy, która stawia dotychczasową akcję w innym świetle i pobudza ciekawość widza co do dalszego jej przebiegu. Może to być także na przykład ujawnienie się jakichś wcześniej ukrywanych cech postaci, które całkowicie zmieniają stosunki między bohaterami lub też pojawienie się nowej osoby wywierającej zasadniczy wpływ na dalszy bieg wydarzeń ${ }^{4}$.

Akt drugi stanowi rozwinięcie sytuacji zarysowanej we wstępie i ma charakter sinusoidalny. Jest to najdłuższa część, której mikrodramaturgia składa się zarówno ze słabszych, jak i z mocniejszych pod względem dramaturgicznym scen. Ogólnie jednak wydarzenia są prezentowane w taki sposób, aby emocje widza sukcesywnie wzrastały, aż do drugiego, najbardziej emocjonującego punktu zwrotnego (climax), po którym następuje chwilowe wyciszenie.

Jego [drugiego aktu - A.W.] zasadniczą częścią jest konfrontacja protagonisty i antagonisty zmierzajaca do kulminacji w postaci drugiego punktu zwrotnego, który przypada zazwyczaj na moment przed końcem owego aktu. Podobnie jak jego odpowiednik z aktu pierwszego, drugi punkt zwrotny ustawia akcję w nowym, zaskakującym kierunku, w istotny sposób odwraca więc bieg zdarzeń i losy bohaterów. Zdarzeniom tym towarzyszy wzrost tempa akcji i dynamiczne podbicie emocji. Po krótkim wybrzmieniu, umożliwiającym zreasumowanie wszystkich ogniw fabuły, rozpoczyna się akt trzeci, w którym następuje rozwiązanie akcji, czyli ostateczna konfrontacja między głównymi stronami konfliktu ${ }^{5}$.

Trzeci akt natomiast - jak zostało zaznaczone powyżej - ma być momentem rozwiązania konfliktu, uspokojenia akcji, dzięki czemu widz ma mieć okazję odetchnać po katharsis osiagniętym w momencie kulminacyjnym. Tu już zachodzi istotna zmiana w zakresie dramaturgii, gdyż emocje odbiorcy w trzecim akcie mają przybierać kształt krzywej opadającej. Akt trzeci, a więc ostatnie trzydzieści minut filmu, to moment, w którym rzeczywistość bohatera wraca do normy, a odbiorca ma czas przygotować się emocjonalnie na konkluzję historii.

\section{Kinowy eksperyment $z$ dramaturgia}

W kinie współczesnym ten paradygmat jest często przełamywany. Za przykład niech posłuży Czarny Łabędź Darrena Aronofsky’ego. Główną

${ }^{4}$ W. Otto, Paradygmat $i$ suspens. O dramaturgii scenariusza filmowego, „Images. The International Journal of European Film, Performing Arts and Audiovisual Communication” 2015, t. XVI, nr 25, s. 75.

${ }^{5}$ Ibidem. 
bohaterka jest tu Nina Sayers - nieśmiała, ale zdeterminowana baletnica rywalizująca o podwójną rolę Odetty i Odylii w Jeziorze łabędzim, o której marzy każda tancerka. Beth Macintyre - primabalerina, której do tej pory przypadało grać główną rolę - weszła już (w oczach środowiska teatralnego) w wiek emerytalny i Nina ma szansę zajać jej miejsce. Wiąże się to jednak z falą zawiści ze strony koleżanek po fachu, koniecznością katorżniczego treningu, całkowitym poświęceniem życia rodzinnego i towarzyskiego na rzecz kariery oraz - jak się okaże - niesie także zagrożenie dla zdrowia psychicznego i tak już rozedrganej emocjonalnie bohaterki. Nina nie jest jednak jedyną tancerka, która ma szansę zostać Królową Łabędzi. Jej najpoważniejszą konkurencja jest pełna wdzięku, przebojowa Lily, która w przeciwieństwie do Niny z łatwością odgrywa także rolę drapieżnej Odylii - mrocznego sobowtóra Odetty. W końcu jednak protagonistka otrzymuje angaż w sztuce i rozpoczynają się próby.

Wraz z postępujacym wycieńczeniem fizycznym i psychicznym bohaterki film nabiera tempa. Dramaturgicznie znajdujemy się w drugim akcie. Nina coraz bardziej pogrąża się $\mathrm{w}$ amoku, nie jest w stanie orzec, co jest prawda, a co halucynacja. Zatraca się w roli, coraz bardziej przeistaczając się z łagodnej, zamkniętej w sobie tancerki we władczą i mściwą Odylię. Miewa halucynacje; pojawiaja się u niej zaburzenia osobowościowe; rzeczywistość przestaje być dla niej (tak jak i dla widza) punktem odniesienia. Granice pomiędzy jawą a koszmarnym snem stają się płynne, niemożliwe do określenia. Tak samo niemożliwa do sprecyzowania i rozdzielenia staje się dwoista natura samej Niny, która z podziwem obserwuje niewymuszoną drapieżność Lily i stara się do niej upodobnić. Odkrywa w sobie pokłady agresji, jakich nigdy by u siebie nie podejrzewała. W związku z tymi zmianami przebudowuje się też relacja Niny z matka - była baletnica, która do tej pory kontrolowała córkę i wpływała na każda jej decyzję. Niewinna i delikatna „słodka dziewczynka” (jak nazywa ją matka), której na próbach doskonale udaje się odtworzyć rolę Białego Łabędzia, z każdym dniem odkrywa na sobie coraz ciemniejsze pióra. Nina z czasem upodabnia się do swojej rywalki i uwalnia swą krępowana przez lata seksualność. Perfekcja, do której tak wytrwale dąży, wiąże się z połączeniem tych dwóch osobowości, uzyskaniem harmonii, okiełznaniem mrocznego, gwałtownego oblicza Czarnego Łabędzia, ale przede wszystkim - z dopuszczeniem go do głosu. To wewnętrzne rozbicie, walka dwóch, wydawałoby się, przeciwstawnych żywiołów prowadzą do kulminacyjnej sceny finałowej. Metaforyczna walka Czarnego i Białego Łabędzia zamienia się w dosłowne starcie: Nina w trakcie przedstawienia okalecza się, wbijając sobie nożyczki w pierś. Z otwartą raną kontynuuje jednak występ. Balet kończy się samobójstwem Odetty, film - samobójstwem baletnicy. 
Wszystkie środki poetyckie, którymi operuje film, są nakierowane na to, aby w widzu wzmocnić wrażenie współodczuwania z Nina. Nie otrzymuje on zatem żadnych informacji poza tymi, które są dostępne bohaterce; nic więc zaskakującego, że sam odbiorca również zaczyna zatracać się w chaosie świata przedstawionego, nie będąc w stanie odróżnić snu od jawy. Estetyka dopełnia w filmie semantykę. Narracja jest zsubiektywizowana poprzez ruch kamery. Płynny steadicam zdaje się tańczyć z baletnicami, przez co włącza widza w zdarzenia, wyrywa go z tradycyjnej pozycji biernego obserwatora. Z drugiej jednak strony wirująca kamera może być klaustrofobiczna i wzmagać poczucie osaczenia. W drugim akcie także coraz więcej elementów scenograficznych ma wzmacniać zaangażowanie widza, pomóc mu przyjąć punkt widzenia bohaterki i wzmocnić efekt projekcji-identyfikacji. Pojawiają się więc szyby i lustra, w których odbijają się wizerunki Niny, przez co odbiorca odczuwa tę samą dezorientację co bohaterka i jak ona kwestionuje prawdziwość rzeczywistości prezentowanej w filmie, nie jest bowiem w stanie ocenić, co jest prawda, a co jedynie lustrzanym odbiciem.

Ponadto Czarny Łabędź sprawnie operuje napięciem dramaturgicznym poprzez wzmocnienie empatii widza wobec bohaterki także w zakresie strategii sposobów przedstawiania ciała. Posługuje się bowiem poetyką kina haptycznego czy afektywnego - ukazuje struktury ciała (gęsią skórkę, pióra wyrastające z pleców), elementy abiektalne (pot, krew, zdarte skórki przy paznokciach) ${ }^{6}$, stosuje także czasami zabieg jump scare'a - typowy dla horrorów (przykładowo w scenach na sali baletowej, przedstawiających powielone, lustrzane wizerunki Niny). Do zabiegów afektywnych można zaliczyć również opisany powyżej chaotyczny ruch kamery, a także efekty stroboskopowe, które pojawiaja się w scenie na dyskotece ${ }^{7}$. Ciała na ekranie wzbudzają naszą reakcję somatyczną (wzdrygnięcie ze strachu, podniecenie, mdłości), co również pomaga nam utożsamić się z bohaterka, i to na głębokim, cielesnym poziomie, gdyż doświadczenie somatyczne widza jest tożsame z doświadczeniem bohaterki.

W latach dziewięćdziesiątych pojęcie haptycznej wizualności wprowadziła Laura Marks ${ }^{8}$, która zauważyła, że wizualność może charakteryzować się

${ }^{6}$ Odnoszę się tu do pojęcia abiektu (wy-miotu), wprowadzonego przez Julię Kristevą w eseju Potęga obrzydzenia. Esej o wstręcie. Najistotniejszą w kontekście haptyczności cechą abiektu jest to, że znajduje się on pomiędzy przedmiotem a podmiotem. Odczuwamy abiekty jako pochodzace z nas albo mające związek z nami, ale z drugiej strony nam obce.

${ }^{7}$ Stosując efekty stroboskopowe, neurotyczny ruch kamery i ogłuszający lub dysharmonijny dźwięk, po mistrzowsku wyrywa widza z toku opowieści i zaprasza w afektywna, deziluzyjną podróż filmową np. Gaspar Noé w swych teledyskowych dziełach, stanowiących często wymagające doświadczenia percepcyjne.

${ }^{8}$ Sformułowała je na Konferencji Młodych Krytyków (La jeune critique aujourd’hui) w Paryżu w 1993 roku w referacie The Haptic Critic, a następnie rozwinęła w artykule Video 
szczególnym rodzajem namacalności, mającym polegać na dotykaniu dzieła audiowizualnego za pomocą oczu. Haptyczne, a więc „dotykalne” są wszelkiego rodzaju kształty i tekstury, które mają angażować inne niż wzrok zmysły widza, zachęcać go do cielesnej interakcji. Przykładami haptycznie naładowanych powierzchni filmu są według Marks zbliżenia określonych płaszczyzn ciała (gęsiej skórki lub innej cielesnej tekstury), brak głębi ostrości czy efekt rozmazania obrazu. Wszystkie te zabiegi zachęcają bowiem nasze oczy do prób wyostrzenia wzroku, identyfikacji rozmytych obiektów, co jest instynktowna reakcją cielesna. Samo ciało widza rozpoznaje ukazane powierzchnie jako podobne do siebie, a więc każda przyjemność i wszelka krzywda, które spotykaja owo ciało na ekranie, sa odczuwane także przez ciało odbiorcy. Podobne przemyślenia towarzyszyły Vivian Sobchack ${ }^{9}$ przy opracowywaniu teorii zmysłowej (sensuous theory). Badaczka opisała doświadczenie filmowe jako system komunikacji oparty na cielesnej percepcji. W kinie znajdujemy się bowiem w sytuacji, w której percypujemy ekspresję, czyli jakiś wyraz artysty, a film z kolei wykorzystuje ekspresję percepcji, tj. mechanizmy, jakie wykorzystujemy na co dzień do odbioru rzeczywistości, nasze sposoby bycia-w-świecie: patrzenie, słuchanie, ruch, orientację w przestrzeni. Obie badaczki rozwinęły więc koncepcje fenomenologiczne, odchodzące od okulocentryzmu, i uznały, że kino nie może już być badane jedynie przez pryzmat wzroku, jako że współczesne dzieła działają synestezyjnie - za pośrednictwem obrazów i dźwięków ewokują wrażenia możliwe do odczytania jedynie za pomoca pozostałych zmysłów (to bowiem nie nasze oczy reaguja, gdy Nina Sayers upada po złamaniu kolan, a nasze ciała, które rozumieją ból związany z łamaniem kości - nawet jeśli nigdy go nie doświadczyły).

W Czarnym Łabędziu afektywnie - a więc natychmiastowo, somatycznie, bezrefleksyjnie - będą działać (poza wspomnianymi już ujęciami pulsującego światła, jump scare'ami oraz ruchem kamery) przede wszystkim wyolbrzymione odgłosy ciała (oddechu, przełykania, uderzania ciała o różne powierzchnie) oraz zachowania autoagresywne Niny - kompulsywne zdzieranie skórek przy paznokciach czy rozdrapywanie ran na ciele.

Cała konstrukcja filmu jest więc od początku do końca nastawiona na wciagnięcie widza w świat baletnicy, na zachęcenie go do porzucenia zmurszałego już dzisiaj układu „mówiące dzieło” / „nieruchomy, bierny widz”. Zgodnie z paradygmatem dramaturgicznym Syda Fielda, Czarny Łabędź powinien więc tym bardziej (skoro tak wiele starań poczynił, aby zbudować zaangażowanie widza) dostarczyć mu oczekiwanego katharsis, aby dopełnić aktu współodczuwania, a następnie, w zakończeniu, dać publiczności

haptics and erotics (,Screen” 1998, t. 39, nr 4) oraz w książce The Skin of the Film: Intercultural Cinema, Embodiment, and the Senses (Durham 2000).

${ }^{9}$ V. Sobchack, Carnal Thoughts: Embodiment and Moving Image Culture, Berkeley 2004. 


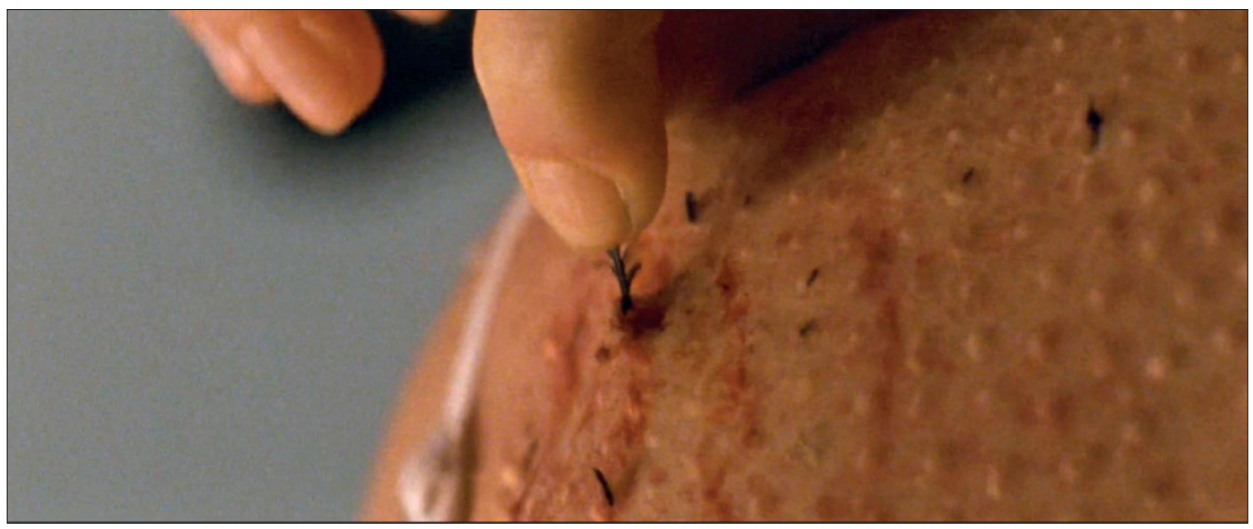

Czarny Łabędź (reż. Darren Aronofsky, 2010). Cielesne przeistaczanie się Niny w łabędzia - przykład haptycznie naładowanej płaszczyzny w filmie.

kilkanaście minut na wyciszenie emocji. Punkt kulminacyjny przypada jednak w Czarnym Eabędziu na sam koniec filmu. Nie występuje tu kilkunastominutowa sekwencja po-kulminacyjna, zakładana w paradygmacie Fielda. Paradoksalnie jednak wrażenie oczyszczenia jest dzięki temu jeszcze silniejsze - pozostawia bowiem widza w zachwycie i oszołomieniu podobnym do tego, które musi czuć Nina, osiagając w końcu artystyczną perfekcję. Ostatnie słowa bohaterki: „Byłam doskonała” wybrzmiewają dzięki temu znacznie silniej. Perfekcyjny występ, a więc nadrzędny cel Niny, do którego dążyła ona w trakcie całego filmu i któremu był podporządkowany rozwój fabuły, zostaje osiagnięty. Zarazem, na poziomie metafilmowym, możliwość ewolucji postaci zostaje zamknięta - w momencie, gdy ta spełnia swoje zadanie, osiaga cel, który przeznaczyła jej fabuła. Protagonistka dociera do pewnej krańcowej granicy zaprojektowanej przez dzieło - perfekcji, poza którą nie rozpościerają się już żadne możliwości kontynuacji fabuły. W tym sensie samo zakończenie filmu jest również doskonałe, gdyż wyczerpuje w pełni stawiane sobie zadania. W wyniku takiego rozłożenia akcentów dramaturgicznych widz jest zostawiony po projekcji w stanie wysokich emocji, dostarczonych przez moment kulminacyjny. Pozbawiony zostaje tym samym możliwości wyciszenia, płynnego przejścia od wrażeń związanych z odbiorem sztuki do swojego codziennego życia. W takiej perspektywie występujące przeciw schematowi rozwiązanie dramaturgiczne przypomina raczej zakończenie charakterystyczne dla teatru. Ma to oczywiście pełne uzasadnienie, jeśli spojrzeć na tematykę filmu Aronofsky'ego. Ostatnią sceną baletu jest bowiem samobójstwo Królowej Łabędzi, a więc także moment kulminacyjny.

Czarny Łabędź niewątpliwie występuje przeciwko tradycyjnym schematom dramaturgicznym, wprowadzając deziluzyjne zakończenie, niezgod- 
ne z przyjęta konwencja, przez co pozostawia widza na koniec w poczuciu pewnego zaskoczenia (pojawia się pytanie: czy to naprawdę koniec?), jako że podświadomie, nauczeni wieloma doświadczeniami kinowymi, oczekujemy trzeciego aktu. Takie zaburzenie klasycznej, konwencjonalnej narracji stanowi potwierdzenie tendencji filmu do eksponowania własnych elementów strukturalnych, a tym samym wpisuje się w szerszy kontekst technik deziluzyjnych widocznych we współczesnej kinematografii.

\section{BIBLIOGRAFIA}

Field S., Rilla R., Pisanie scenariusza filmowego, przeł. W. Wertenstein, B. Pankau, Warszawa 1998.

Kristeva J., Potęga obrzydzenia. Esej o wstręcie, przeł. M. Falski, Kraków 2007.

Marks L., The Skin of the Film: Intercultural Cinema, Embodiment, and the Senses, Durham 2000.

Marks L., Video haptics and erotics, „Screen” 1998, t. 39, nr 4.

Otto W., Paradygmat $i$ suspens. O dramaturgii scenariusza filmowego, „Images. The International Journal of European Film, Performing Arts and Audiovisual Communication” 2015, t. XVI, nr 25.

Propp V. Âkovlevič, Morfologia bajki magicznej, przeł. P. Rojek, Kraków 2011.

Sobchack V., Carnal Thoughts: Embodiment and Moving Image Culture, Berkeley 2004.

Adrianna Woroch - dr, Instytut Filmu, Mediów i Sztuk Audiowizualnych na Uniwersytecie im. Adama Mickiewicza w Poznaniu, filmoznawczyni. Zajmuje się współczesnym kinem bliskowschodnim, poststrukturalna teorią kina, autorefleksyjnością w kinie oraz związkami filmu i innych mediów. Kierowniczka grantu Rozpad wewnętrznych ram dzieła filmowego. Techniki deziluzyjne w kinie wspótczesnym. Autorka monografii poświęconej twórczości Paola Sorrentina pt. Kicz i piękno w twórczości Paola Sorrentina na przyktadzie dziet: „Wielkie piękno”, „Młody papież”, „Wszystkie odloty Cheyenne'a” oraz „Młodość”. ORCID: 0000-0003-4237-3756. Adres e-mail: <adrwor@amu.edu.pl>.

Adrianna Woroch - PhD, Institute of Film, Media and Audiovisual Arts at Adam Mickiewicz University in Poznan; film scholar; interested in contemporary Middle Eastern cinema, poststructural film theory, self-reflexivity in cinema, as well as the relationships between film and other media. Head of the grant project entitled Disintegration of the internal framework of a film work. Disillusionment techniques in contemporary cinema. Author of a monograph devoted to the works of Paolo Sorrentino, entitled Kicz i piękno w twórczości Paola Sorrentina na przyktadzie dziet: „Wielkie piękno”, „Młody papież”, „Wszystkie odloty Cheyenne'a” oraz „Młodośc” [Kitsch and beauty in the works of Paolo Sorrentino on the example of: 'The Great Beauty', 'The Young Pope', 'This Must Be the Place' and 'Youth']. ORCID: 0000-0003-4237-3756. E-mail address: <adrwor@ amu.edu.pl>. 


\title{
Monika Błaszczak \\ Szorstki i chropowaty dotyk - o dramaturgii zmysłów
}

\begin{abstract}
Monika Błaszczak, Szorstki i chropowaty dotyk - o dramaturgii zmysłów [Rough and harsh touch - on the dramaturgy of the the senses]. „Przestrzenie Teorii” 36. Poznan 2021, Adam Mickiewicz University Press, pp. 229-255. ISSN 1644-6763. DOI 10.14746/pt.2021.36.14.

Today, the concept of dramaturgy refers primarily to the space of theater or, more broadly, to performative arts. But as the concept of drama has passed into the scientific discourse of sociology, anthropology or literary studies, so is it with dramaturgy. The understanding that appears here refers to its meaning as a special tension on the level of sensually experienced and perceived artistic events. The subject of interest here is the dramatic aesthetics of experience in the field of performing and visual arts. The aesthetic categories related to the senses are often of a physical origin and amorphous in nature. The roughness and harshness of the title in their origin are physical categories that can be experienced primarily through the sense of touch. In this intertwining of senses, we are talking about their dramaturgy, because they cannot usually be separated from each other and various works appeal to touch and other senses at the same time. The process of creating a work and its reception is an action, process, meeting, the playwright of which is both the creator / creator and the recipient. The considerations concern changes in the perception of the senses, from the glorification of the sense of sight to the ennoblement of the "lower" senses, the place and function of the classical and interactive museum and haptic art, as well as the polysensory and immersive reception designed in performance and theater.
\end{abstract}

KEYWORDS: rough, touch, senses, haptic, affect, dramaturgy, transcategories, museum, performance, mltisensory, immersion

Jeśli wybierasz się w podróż niech będzie to podróż dtuga wędrowanie pozornie bez celu btadzenie po omacku żebyś nie tylko oczami ale także dotykiem poznat szorstkość ziemi $i$ abyś cata skórq zmierzyt się ze światem ${ }^{1}$.

Czy można mówić o dramaturgii zmysłów? Pojęcie dramaturgii odnosi się dzisiaj przede wszystkim do przestrzeni teatru czy szerzej - sztuk performatywnych. Ale jak pojęcie dramatu przeszło do dyskursu naukowego: socjologicznego, antropologicznego czy literaturoznawczego, tak podobnie dzieje się z dramaturgią. Pojawiające się tu rozumienie dramatu odwołuje do jego znaczenia jako szczególnego napięcia na poziomie zmysłowo doświadczanych i postrzeganych zdarzeń artystycznych. Przedmiotem zainteresowania jest tu dramaturgiczna estetyka doświadczenia w obszarze sztuk performatywnych i wizualnych.

${ }^{1}$ Z. Herbert, Podróż, [w:] idem, Elegia na odejście, Wrocław 1993, s. 24. 


\section{Od gloryfikacji zmysłu wzroku do nobilitacji zmysłów "niższych"}

Kategorie estetyczne wiążące się ze zmysłami mają często źródło fizykalne i charakter amorficzny. Z pojęciem zmysłów sa ściśle powiązane teoria afektów i koncepcja żywiołów. Jednocześnie nie sposób nie odwołać się do pojęcia doświadczenia estetycznego, w którym obcowanie z dziełem sztuki, literatury, teatru czy sztuk performatywnych można postrzegać i analizować poprzez te właśnie kategorie. Szorstkość i chropowatość to w swym rodowodzie fizykalne kategorie możliwe do doświadczenia przede wszystkim poprzez zmysł dotyku. Choć można i tę szorstkość czy chropowatość zobaczyć na przykład na obrazach, to jednak gdyby istniała możliwość wejścia w interakcję z dziełem, wolelibyśmy dotknąć ich nieregularnej, pofałdowanej, wypukłej czy wklęsłej faktury, żeby w pełni ich doświadczyć. A dotyk to najbardziej zaniedbany zmysł, należy więc uważnie mu się przyjrzeć. W tym splocie zmysłów mowa o ich dramaturgii, gdyż zwykle nie da się ich od siebie oddzielić; różne dzieła odwołują się jednocześnie do dotyku i do innych zmysłów. Proces powstania dzieła i jego odbioru jest akcja, procesem, spotkaniem, którego dramaturgiem jest zarówno sam twórca (twórcy), jak i odbiorca.

Zaproponowane w tytule pojęcia mają wymiar transkategorii, jak je nazwała Mieke $\mathrm{Bal}^{2}$. W słownikach języka polskiego znajdziemy obok siebie terminy: „chropawość”, „chropowatość”, które są definiowane jako coś, co „ma na powierzchni dużo drobnych, twardych wypukłości. [...] Chropawy głos lub dźwięk jest niski, niemelodyjny i matowy. [...] Jako chropawe możemy określić coś, np. czyjś język lub sposób zachowania, co nie jest idealne i wymaga jeszcze pracy, aby stało się doskonalsze" ${ }^{3}$. Rzeczy szorstkie są definiowane podobnie, jako takie, które sa , pokryte drobnymi twardymi wypukłościami i bywają w dotyku nieprzyjemne. [...] Ktoś, kto jest szorstki, zachowuje się niedelikatnie. Także o słowach lub zachowaniu takiej osoby"4. W internetowym Słowniku jezzyka polskiego PWN wskazano także na użycia tego słowa w stosunku do dźwięków i odgłosów: nieczyste, brzmiące przenikliwie ${ }^{5}$. Słowa „szorstki” i „chropowaty” mimo swej częściowej synonimiczności mają nieco inne zakresy znaczeniowe. „Szorstki”

${ }^{2}$ M. Bal, Wędrujace pojęcia $w$ naukach humanistycznych. Krótki przewodnik, przeł. M. Bucholc, Warszawa 2012.

${ }^{3}$ Inny słownik języka polskiego, t. I: A...Ó, red. M. Bańko, Wydawnictwo Naukowe PWN, Warszawa 2000, s. 176.

${ }^{4}$ Inny słownik języka polskiego, t. II: P...Ż, red. M. Bańko, Wydawnictwo Naukowe PWN, Warszawa 2000, s. 759.

${ }^{5}$ Stownik języka polskiego PWN, https://sjp.pwn.pl/slowniki/szorstki.html (dostęp: 23.05.2020). 
dodatkowo występuje jako określenie niestosownego języka czy obcesowego sposobu mówienia (odnośnie czegoś nieprzyjemnego ${ }^{6}$ ). Te różne znaczenia mogą służyć jako tropy interpretacyjne w dalszych rozważaniach. Mówiąc o tym, co chropowate/szorstkie, należy zawsze mieć świadomość drugiego bieguna, czyli ich antonimii - gładkości ${ }^{7}$.

W tych wszystkich kontekstach, znaczeniach, perspektywach chciałabym ukazać na przykładach dramatyczny i dramaturgiczny charakter tytułowych kategorii. Z tego długiego wyliczenia językowych uwikłań terminów „chropowatość”, „,szorstkość” i „gładkość” wyłania się splot nie tylko znaczeń, lecz także ich nacechowania emocjonalnego - dramaturgii emocji. „Chropowate” i „szorstkie” są często nacechowane negatywnie, dotyczą tego, co nieprzyjemne, trudne, nieoczywiste, podczas gdy „gładkie” kojarzy się z tym, co pozytywne i przyjemne (choć może być jedynie pozorem, pod którym kryją się dwie pierwsze cechy). Warto prześledzić te konotacje w literaturze, teatrze i sztukach wizualnych w kontekście szerokiego ujęcia pojęcia dramaturgiczności.

\section{Muzeum klasyczne, czyli "Nie dotykaj!”. Od wystawy za ozdobnym sznurem (w kapciach na nogach)...}

Obcowanie z dziełem sztuki w pierwszym skojarzeniu postrzegamy jako odbywające się $\mathrm{w}$ przestrzeni muzeum czy galerii, polegające na patrzeniu na dzieło z pewnej odległości i obwarowane zakazem „nie dotykać!”. Jak słusznie zauważa współczesna badaczka i kuratorka sztuki Marta Smolińska: „Personel skwapliwie pilnuje zwiedzających, by zachowali odpowiedni dystans wobec dzieł sztuki i kontemplowali je jedynie wzrokiem. A tymczasem niektóre realizacje artystyczne kuszą i uwodzą także dotyk - nie pozostaje nam jednak nic innego, jak przestrzegać muzealnego regulaminu, dotykając dzieł jedynie spojrzeniem i wyobrażając sobie ich fakturę pod naszymi palcami...”. Najlepszą ilustracją niezmienności tych odbiorczych wytycznych w wielu muzeach i galeriach będzie doświadczenie osobiste.

${ }^{6}$ Stownik synonimów, https://synonim.net/synonim/szorstki (dostęp: 23.05.2020).

${ }^{7}$ „Coś, co jest gładkie, ma powierzchnię pozbawioną jakichkolwiek nierówności. [...] Gładkie jezioro, morze, [...] Gładki materiał, papier itp. [...] Gładkie ubranie. [...] Gładkie uczesanie, włosy itp. [...] 6 Gładkie słowa i wypowiedzi są uprzejme i sprawiają takie wrażenie, jakby przychodziły mówiącego bez trudu. [...] 7 Ktoś, kto jest gładki, jest miły i uprzejmy. Słowo nieco przestarzałe". Za: Inny słownik języka polskiego, t. I: A...Ó, ed. cit., s. 447-448.

${ }^{8}$ M. Smolińska, (Nie) dotykaj! Haptyczne aspekty sztuki polskiej po 1945 roku, https:// csw.torun.pl/sztuka/wystawy/wystawa-nwystawa-nie-dotykaj-haptyczne-aspekty-sztuki-polskiej-po-1945-rokuie-dotykaj-haptyczne-aspekty-sztuki-polskiej-po-1945-roku-4090/ (dostęp: 20.04.2021). 
Wchodzimy do wnętrza Zamku w Kórniku koło Poznania i na progu wita nas kosz z filcowymi kapciami. To pierwszy próg dostępu, poza oczywiście zakupieniem biletu. Potem wysokie schody bez jakichkolwiek udogodnień dla mniej sprawnych czy dziecięcych zwiedzających - drugi próg.9. Wszystkie eksponaty sa pochowane w gablotach, witrynach, za szybami, sznurami i innymi elementami - trzeci próg. Do tego bardzo krótki czas otwarcia instytucji dla zwiedzajacych - w godzinach 10.00-16.00 - czwarty próg. Wiele muzeów nadal funkcjonuje na takich właśnie zasadach.

Należy jednak zauważyć, iż sytuacja powoli się zmienia. Wystawy interaktywne, w ramach których można doświadczać obcowania z artefaktami i dziełami sztuki przez pozostałe zmysły, w tym zwłaszcza przez dotyk, to coraz częściej pojawiające się formy kontaktu odbiorczego. Przestrzeń ekspozycji nie może już dziś być projektowana jako sfera tabu, w której wszystkie artefakty są dla odbiorcy nietykalne. Jednak wiele muzeów zamkowych czy wielkich galerii sztuki nadal utrzymuje taką formułę i na niewiele pozwala odwiedzającym je osobom. Wynika to z utrwalonych nawyków po obu stronach - i twórców, i odbiorców dzieł prezentowanych w ramach różnych ekspozycji. Tradycyjna definicja muzeum, od greckiego źródłosłowu mouseíon - 'świątynia muz' i łacińskiego musaeum, mówi o „instytucji, której zadaniem jest gromadzenie i przechowywanie materialnych świadectw cywilizacji człowieka i jego otoczenia, ich naukowe opracowywanie, konserwowanie i udostępnianie w celu badań, nauczania i rozrywki" ${ }^{10}$. W tych definicjach podkreśla się, że prezentowane obiekty muszą mieć wartość historyczną bądź artystyczną i że w większych placówkach tylko niewielka część zbiorów jest udostępniana publiczności $\mathrm{w}$ postaci wystaw stałych lub czasowych, a resztę przechowuje się $\mathrm{w}$ magazynach. W XX wieku muzea przekształciły się w aktywne placówki naukowe i oświatowe, zmodernizowano metody ekspozycji, wzniesiono wiele nowoczesnych gmachów muzealnych ${ }^{11}$.

Sami muzealnicy zauważają nieadekwatność tradycyjnego postrzegania tych instytucji i coraz częściej dostrzegają konieczność zmian. Na pytanie: „czym jest muzeum dzisiaj?” próbuje odpowiedzieć Dorota Folga-Januszew-

${ }^{9}$ Od tej wizyty sprzed kilku lat coś się jednak zmieniło - zamontowano windę. Zob. https:// kornik.travel/pl/obiekty/zwiedzanie/zamek-w-korniku?gclid=Cj0KCQjw9_mDBhCGARIsAN3PaFPpwAVNuWd0HkhoutucM8fSsYaBxs8vW3p5AsmInyRsLX2purAgLHQaAugTEALw_wcB (dostęp: 20.04.2021).

${ }^{10}$ https://encyklopedia.pwn.pl/haslo/muzeum;3944738.html (dostęp: 23.04.2021).

${ }^{11}$ Ciekawym aspektem jest strona techniczna tworzenia wystaw i ekspozycji interaktywnych, otwartych na współuczestnictwo. Powstaja firmy, które specjalizują się w przygotowywaniu takiego zaplecza, jak np. Multimedialne Muzeum, które jest marką agencji interaktywnej bozanta.pl, powstałej w 2009 roku. W ofercie ma multimedialne aplikacje, aranżacje ekspozycji czy oprawy graficznej. Zob. https://multimedialnemuzeum.pl/ (dostęp: 23.04.2021). 
ska, która cytuje Georges'a Henriego Rivière'a: „Muzeum jest instytucją trwała, o charakterze niedochodowym, służąca społeczeństwu i jego rozwojowi, dostępną publicznie, która prowadzi badania nad świadectwem ludzkiej działalności i otoczenia człowieka, gromadzi zbiory, konserwuje je i zabezpiecza, udostępnia je i wystawia, prowadzi działalność edukacyjną i służy rozrywce"12. Muzea należałoby jednak dostosować do współczesnych realiów, zwłaszcza rewolucji elektronicznej, która dostarczyła narzędzi właściwie nieograniczonego gromadzenia danych: wizerunków, dokumentów, programów, wszelkich zapisów. Potencjalnie każda większa elektroniczna baza danych jest wirtualnym muzeum lub archiwum z jakiejś dziedziny. W latach dziewięćdziesiątych XX wieku pojawiło się pojęcie „muzeum wirtualnego". Takie placówki mogą wypełniać wszystkie funkcje wymienione w wyżej cytowanej definicji muzeów. Przede wszystkim jednak do zadań muzeów wymienionych na wstępie dochodzi działalność kreacyjna - tworzenia kultury, rzeczywistości, czasem sztuki realizowanej w cyfrowym obszarze wirtualnym ${ }^{13}$. Muzeum interaktywne jest definiowane jako „zlokalizowane w przestrzeni rzeczywistej (tj. w konkretnym budynku lub pomieszczeniu) nowoczesne muzeum, którego głównym zadaniem jest wieloperspektywiczne przekazanie zwiedzającym jakiejś idei, zdarzeń, zagadnień, które wykorzystuje do tego celu ekspozycje stworzone z różnych środków przekazu, takich jak: multimedia (filmy, muzyka, prezentacje multimedialne, wizualizacje), oryginalne eksponaty i fotografie czy interaktywne formy prezentacji (scenografia, repliki, makiety, których każdy może dotknąć)"14. Najważniejszy w nich jest bezpośredni kontakt, czyli interakcja między widzem a ekspozycja, oddziałująca w sposób polisensoryczny, czyli na różne zmysły zwiedzającego (wzrok, słuch, węch, dotyk, smak).

Bardzo ciekawą koncepcję muzeum krytycznego przedstawił Piotr Piotrowski w książce będącej podsumowaniem jego pracy w Muzeum Narodowym w Warszawie. Zwraca w niej uwagę na potrzebę muzeum rozumianego jako forum zaangażowane $\mathrm{w}$ debatę publiczna, podejmujące ważne problemy (często kontrowersyjne), którymi żyje społeczeństwo, postrzeganego jako instytucja pracujaca na rzecz demokracji opartej na sporze. Muzeum krytyczne to także instytucja autokrytyczna, rewidująca własną tradycję, mierząca się z własnym autorytetem oraz kanonem historyczno-artystycznym, który sama ukształtowała ${ }^{15}$.

${ }^{12}$ G.H. Rivière, La muséologie selon, Paris 1989, [cyt. za:] D. Folga-Januszewska, Muzeum: definicja i pojęcie. Czym jest muzeum dzisiaj?, „Muzealnictwo” 2008, nr 49, s. 200.

${ }^{13}$ D. Folga-Januszewska, op. cit., s. 200, 201.

${ }^{14}$ M. Stefanik, M. Kamel, Muzea i wystawy interaktywne w Polsce - wspótczesna atrakcja turystyczna, „Turystyka Kulturowa” 2013, nr 8, s. 9.

${ }^{15}$ P. Piotrowski, Muzeum krytyczne, Poznań 2011. 
A przecież nie chodzi o to, żebyśmy dotykali cennych obrazów czy rzeźb, ale żeby nam zostawiono miejsce na jaką́ inną zmysłową aktywność poza patrzeniem. Jak pisze Maria Popczyk, wizja muzeum przeszła ewolucję i współcześnie najbardziej adekwatne wydaje się ,porzucenie myślenia o muzeum jako miejscu zachowującym te same co w XIX wieku sposoby podejścia do artefaktów przyrody i dzieł sztuki oraz wykazanie, że w muzeum dokonuje się daleko idace przeformułowanie tego podejścia. Jest oczywiste, że jako sprawnie działająca instytucja muzeum podlega modernizacji, która zawsze w jakimś stopniu dotyczy ekspozycji, chodzi jednak o coś więcej, mianowicie wraz z tymi zmianami samo muzeum zyskuje nową postać, nie jest już autonomicznym miejscem kontemplacji dzieł, jak twierdzi Odo Marquard czy Arthur Danto, ale staje się miejscem interakcji z odbiorcą"16.

\section{... do ekspozycji haptycznych. Muzeum interaktywne/ performatywne, czyli "Działaj i dotknij"}

Zatem muzea i galerie stają się współcześnie miejscami pełniącymi nie tylko funkcję archiwów, czyli ochronna, która polega na tym, że gromadzi się i przechowuje cenne artefakty i dzieła sztuki. Coraz częściej realizacja podstawowych funkcji tych miejsc opiera się nie na przechadzaniu się po salach i oglądaniu ekspozycji z zachowaniem odpowiedniego dystansu pod czujnym okiem osób pilnujących, by tej granicy nie naruszyć, ale na działaniu, interakcji, wejściu w bliższą relację z eksponatami, z opowiadana przez nie historia, z estetyką miejsca i pracownikami. Funkcje: edukacyjna, naukowa, kulturalna, wychowawcza i estetyczna zyskują swój nowy, dużo bardziej „namacalny” wymiar.

Pojawiaja się interaktywne, a nawet performatywne miejsca kontaktu z dziełami sztuki i śladami przeszłości. Przykłady można mnożyć, bo jest to obecnie silny trend: Brama Poznania, czyli ICHOT ${ }^{17}$, Muzeum Powstania Warszawskiego ${ }^{18}$, Muzeum Krakowa ${ }^{19}$, Centrum Nauki Kopernik ${ }^{20}$ czy

${ }^{16}$ M. Popczyk, Estetyczne przestrzenie ekspozycji muzealnych. Artefakty przyrody i dzieła sztuki, Kraków 2008, s. 10.

17 „Brama Poznania to przede wszystkim ekspozycja. Myli się jednak ten, kto myśli, że będzie to kolejne nudne zwiedzanie pod hasłem «Nie dotykać!». U nas jest odwrotnie. Zachęcamy: zakręć, przymierz, zagraj, dotknij”. Zob. https://bramapoznania.pl/oferta-dla-rodzin-z-dziecmi (dostęp: 23.04.2021).

${ }^{18} \mathrm{https}: / /$ www.1944.pl/artykul/tajne-komplety-czyli-zwiedzaj-muzeum-inaczej-ni,5114. html (dostęp: 23.04.2021).

${ }^{19} \mathrm{https}: / /$ muzeumkrakowa.pl/cykle/program-edukacyjny-towarzyszacy-wystawie-w-chocholim-tancu (dostęp: 23.04.2021).

${ }^{20} \mathrm{https}: / /$ www.kopernik.org.pl/wydarzenia (dostęp: 23.04.2021). 
Muzeum Bajek, Baśni i Opowieści MuBaBao w Czarnowie ${ }^{21}$. Poza tym trzeba podkreślić, iż muzea i galerie sztuki to nie tylko budynki, lecz także tereny postindustrialne, parki, ogrody czy inne otwarte przestrzenie, które przez swój nietypowy charakter otwierają się na inny sposób komunikacji i relacji z odbiorca.

Otwarcie na odbiorcę to znoszenie wymienionych na początku progów: od tych najoczywistszych, czyli architektonicznych, przez filcowe kapcie, złocone sznury i szklane witryny, po dopuszczenie publiczności do głosu i działania, czyli do aktywności, współkreowania, uruchamiania wszystkich zmysłów. Choć warto tu też zauważyć, że najwięcej miejsca na eksplorację przez działanie dostaja dzieci, dla których w wielu takich przestrzeniach pojawiaja się miejsca do aktywnego uczestnictwa, dodatkowych zabaw edukacyjnych czy bardziej interaktywnego zwiedzania.

Coraz częściej pojawiają się wystawy i projekty performatywne adresowane do osób niewidzących i niedowidzących, mocno odwołujące się nie tylko do sfery dźwiękowej, lecz także dotykowej. W 2013 roku zorganizowano wystawę Dotknać obrazu - Malczewski, Szymborska, Antoniszczak ${ }^{22}$ w ramach szerszego projektu pod nazwa Dotknij kultury. We wspomnianym już Muzeum Historycznym Miasta Krakowa, mającym niezwykle szeroką ofertę działań i współuczestnictwa (warsztaty, oprowadzenia kuratorskie i tematyczne, spacery, wycieczki rowerowe, dyskusje czy panele), ten aspekt też jest mocno eksponowany. Szczególnie ciekawym pomyłem jest aranżacja wystawy Kraków - czas okupacji 1939-1945 w oddziale Fabryka Schindlera, udostępniona widzom z niepełnosprawnością wzroku i słuchu w ramach programu Deklaracji dostepności. Jak piszą na stronie wydarzenia organizatorzy: „Jest to pierwsze tego typu przedsięwzięcie w Muzeum Historycznym Miasta Krakowa, przygotowane we współpracy z Fundacja Kultury bez Barier i Fundacją Dzieciom Zdążyć z Pomoca w ramach projektu Muzeum Poza Cisza i Ciemnością dofinansowanego przez Ministra Kultury i Dziedzictwa Narodowego. Poniżej zamieszczone zostały pliki mp3 z audiodeskrypcją wystawy, do pobrania na telefon lub odtwarzacz mp3. Każdy z audiodeskrypcyjnych tekstów składa się z dwóch części - opisu sali lub konkretnego eksponatu oraz opisu merytorycznego prezentowanego na wystawie zagadnienia. Podczas zwiedzania wystawy osoby niedowidzące i niewidome będą mogły również skorzystać z materiałów tyflograficznych, czyli wypukłych modeli ułatwiajacych odtworzenie

${ }^{21}$ https://www.facebook.com/Muzeum-Bajek-Ba\%C5\%9Bni-i-Opowie\%C5\%9Bci-Storyteller-Museum-128032343954199; http://mubabao.pl/ (dostęp: 23.04.2021).

${ }^{22}$ Dotknać obrazu-Malczewski, Szymborska, Antoniszczak, Muzeum UJ Collegium Maius, 14.10 - 6.12.2013, http://www.dotknijkultury.pl/pl/poprzednie-edycje/2013/wydarzenia/ wystawa-dotknac-obrazu (dostęp: 7.07.2020). 
w wyobraźni wybranych elementów ekspozycji. Dla osób niesłyszących i niedosłyszących przygotowane zostały wideo tłumaczenia (na język migowy) oraz napisy do wybranych prezentacji multimedialnych i filmów, a także opracowano przewodnik po dźwiękach wystawy, które tworza jej integralną część, a bez których jej odbiór jest niepełny" ${ }^{23}$. Takie podejście staje się coraz bardziej powszechne, czego przykładem może być poznański projekt realizowany przez Centrum Kultury Zamek Sztuka w ciemno. Cykl zdalnych warsztatów sensualnych ${ }^{24}$.

Ciekawym zjawiskiem, które zmienia sposób odbioru na polisensoryczny, jest sztuka haptyczna. Różnica między zmodernizowaniem odbioru tradycyjnych artefaktów i dzieł sztuki a sztuką haptyczna polega na tym, że ta druga zakłada jako podstawę odbioru dotyk. Aneta Rostkowska, współczesna badaczka i kuratorka sztuki, definiuje sztukę haptyczna jako „dzieła sztuki, których głównym sposobem doświadczenia jest zmysł dotyku”, odróżniając je jednocześnie od „dzieł sztuki, których jednym z głównych tematów jest zmysł dotyku". Haptyczne dzieło sztuki należy do tej pierwszej kategorii, a więc jako takie, które ukazuje się w pełni dopiero w kontakcie dotykowym, a „odbiór dzieła z pominięciem tego zmysłu spowoduje niepełne uobecnienie się w doświadczeniu odbiorcy" ${ }^{25}$. Od strony przedmiotowej dzieło tego typu charakteryzuje się głównie własnościami, których można bezpośrednio doświadczyć jedynie z użyciem zmysłu dotyku, takimi jak: miękkość/twardość, mniejsza lub większa spoistość, własności termiczne (ciepło/zimno), mokre/suche, sztywność/giętkość, napięcie/luźność, śliskość/opór, kruchośćl siła, lekkość/ciężkość (jeśli źródłem dotyku jest sam artysta - czego można doświadczyć na przykład w performansie - do tej listy można dodać specyficzne rodzaje dotyku: głaskanie, popychanie, obejmowanie, policzek itd.). „Zmysł dotyku nie jest w nim potraktowany czysto instrumentalnie, a więc jako środek dotarcia do własności innego, niedotykowego typu, lecz jako istotny środek dotarcia do treści dzieła” ${ }^{26}$.

Z kolei Marta Smolińska, inna badaczka haptyczności, była kuratorka wystawy o znamiennym tytule (Nie) Dotykaj! Haptyczne aspekty sztuki polskiej po 1945 roku, prezentowanej w Centrum Sztuki Współczesnej w Toruniu w $2015 \mathrm{roku}^{27}$. Ekspozycja została podzielona na dwie części: w pierwszej

\footnotetext{
${ }^{23} \mathrm{https}: / /$ muzeumkrakowa.pl/muzeum-bez-barier (dostęp: 20.04.2021).

${ }^{24} \mathrm{https}: / /$ sztukawciemno.pl/ (dostęp: 20.04.2021).

${ }^{5}$ A. Rostkowska, Haptyczne dzieło sztuki, [w:] Materia sztuki, red. M. Ostrowicki, Kra-
} ków 2010, s. 298, 300.

${ }^{26}$ Ibidem, s. 300.

${ }^{27}$ Wystawa (Nie) Dotykaj! Haptyczne aspekty sztuki polskiej po 1945 roku była prezentowana w Centrum Sztuki Współczesnej w Toruniu w dniach 11.04 - 17.05.2015. Artyści: Basia Bańda, Marcin Berdyszak, Beata Ewa Białecka, Tomasz Ciecierski, Dawid Czycz, Iwona Demko, Barbara Falender, Krzysztof Gliszczyński, Martyna Grzeszczak, Małgorzata 
odbiorcy mogli dotykać dzieł sztuki realnie, w drugiej - jedynie wzrokiem. Kuratorka tak tłumaczyła swoja koncepcję: „Pojęcie 'haptyczny' (od greckiego haptein) oznacza zarówno chwytanie i dotykanie w dosłownym sensie, jak i dotykanie wzrokiem, uczucie 'jakby się dotykało'. [...] Pierwsza z nich umożliwia odbiorcom realny, dotykowy kontakt z wybranymi dziełami [...]. Jest zaaranżowana niczym otwarty 'plac zabaw', na którym zwiedzający moga wchodzić $\mathrm{w}$ interakcje $\mathrm{z}$ wystawionymi pracami (oczywiście w sposób zgodny z instrukcjami sformułowanymi przez twórców). Druga zaś prezentuje takie dzieła, które wyjątkowo silnie uwodzą zmysł dotyku, lecz moga być dotykane jedynie wzrokiem [...]. Napięcie pomiędzy uwodzeniem dotyku a niemożnością realnego dotknięcia wynika w tym wypadku najczęściej z potrzeby chronienia dzieł przed zniszczeniem" ${ }^{28}$. Dramaturgia polega tu na uruchomieniu cielesności percepcji - poprzez skórę jako powierzchnię dotyku. Odbiór takiej sztuki jest zatem somatyczny, odwołuje się do tego, co intuicyjne i emocjonalne.

Owa badaczka i historyczka sztuki w wydanej niedawno książce Haptyczność poszerzona. Zmyst dotyku w sztuce polskiej drugiej połowy XX i poczatku XXI wieku ${ }^{29}$ tytułową haptyczność widzi bardzo szeroko: „bardziej interesuje mnie zatem kwestia w pewnym sensie odwrotna: co wydarzy się z percepcja, gdy - zamiast sztucznie oddzielać od siebie doznania zmysłowe - spojrzeć na nie całościowo wraz z udziałem słuchu, smaku i węchu oraz zmysłów równowagi i kinestetycznego. Jak wielozmysłowa, poszerzoną i somaestetyczną definicję haptyczności trzeba byłoby wówczas zaproponować, by opisała ona wieloaspektowość tych wrażeń, obejmujących całe ciało?" ${ }^{30}$. Haptyczność staje się dla niej modalnością wzroku, lecz również słuchu, smaku i węchu, a także zmysłu równowagi i zmysłu kinestetycznego (propriocepcja). Badaczka wskazuje na „multisensoryczny, somaestetyczny i synestetyczny wymiar haptyczności” ${ }^{31}$. Powołuje się przy tym na inspirację,

Kalinowska, Bartosz Kokosiński, Maciej Kurak \& Max Skorwider, Kamil Kuskowski, Paweł Łubowski, Karina Marusińska, Paweł Matyszewski, Magda Moskwa, Justyna Olszewska, Ewa Partum, Włodzimierz Pawlak, Andrzej Pawłowski, Maria Pinińska-Bereś, Krystyna Piotrowska, Damian Reniszyn, Erna Rosenstein, Aleksandra Ska, Marian Stępak, Alina Szapocznikow, Beata Szczepaniak, Grzegorz Sztwiertnia. Zob. https://csw.torun.pl/sztuka/ wystawy/wystawa-nwystawa-nie-dotykaj-haptyczne-aspekty-sztuki-polskiej-po-1945-rokuie-dotykaj-haptyczne-aspekty-sztuki-polskiej-po-1945-roku-4090/ (dostęp: 23.04.2021).

${ }^{28} \mathrm{https}: / / \mathrm{csw}$.torun.pl/sztuka/wystawy/wystawa-nwystawa-nie-dotykaj-haptyczne-aspekty-sztuki-polskiej-po-1945-rokuie-dotykaj-haptyczne-aspekty-sztuki-polskiej-po-1945-roku-4090/ (dostęp: 23.04.2021).

${ }^{29}$ M. Smolińska, Wprowadzenie, [w:] eadem, Haptyczność poszerzona. Zmyst dotyku w sztuce polskiej drugiej połowy XX i poczatku XXI wieku, Kraków 2020.

${ }^{30}$ Ibidem, s. 13.

${ }^{31}$ Ibidem, s. 13. 
jaka jest tekst Wojciecha Bałusa ${ }^{32}$, który wskazał dotykanie wzrokiem jako istotę haptyczności w ramach klasycznej nauki o sztuce. Badacz wywiódł poglądy Aloisa Riegla z tekstów Adolfa Hildebranda i Roberta Vischera, którzy pisali o „symbolicznym” czy metaforycznym traktowaniu dotyku i uruchamianiu go w ramach tzw. aktywnego patrzenia, wykorzystującego zapamiętane wrażenia dotykowe.

Zmysły od wieków dzielono na tzw. wyższe - wzrok i słuch oraz niższe - smak, węch, dotyk. Na polu filozoficznym i estetycznym przez wieki toczyły się spory o istotę piękna i wagę poszczególnych zmysłów. Wzrok był zmysłem uprzywilejowanym. „Estetyka wizualna to opowieść snuta przez barwy i kształty, które "wiążą", "przytrzymują" nasze spojrzenie, które nasze oko napotyka i przy których zatrzymuje się na dłużej” ${ }^{33}$. Następny co do ważności po wzroku był słuch. Starożytni Grecy uważali, że jedynie uszy będą w stanie usłyszeć harmonię, a oczy dostrzegą symetrię. Zmysły dotyku, smaku i węchu były nazywane nie tylko niższymi, lecz także ciemnymi i kanibalistycznymi, związanymi z instynktem przeżycia, cielesnościa, materialnością bytu, z ludzką naturą tą bardziej zwierzęca, cielesną, mniej cywilizowana. Autorstwo tradycyjnego modelu pięciu zmysłów (wzrok, słuch, dotyk, zapach, smak) jest przypisywane Arystotelesowi. Filozof podkreślał uprzywilejowane miejsce wzroku na tle pozostałych zmysłów, jednocześnie dostrzegając ważną rolę dotyku w zdolności przetrwania ${ }^{34}$. Analizując relację poznania, dostrzegał przede wszystkim, iż wszelkie informacje docierają do nas poprzez zmysły. Rzeczywiste poznanie świata ma naturę pojęciowa, ale aby coś zrozumieć i stworzyć tego pojęcie, musimy najpierw doświadczyć tego zmysłami. Rodzimy się bowiem, nie będąc wyposażonymi w żadne terminy i idee; tylko zmysły moga je nam udostępnić i unaocznić.

Długo uważano, że człowiek jest w stanie doświadczyć przeżycia estetycznego za pomocą zmysłów wyższych, czyli wzroku i słuchu, zwierzęta natomiast mogą czerpać przyjemność za pośrednictwem zmysłów niższych: smaku i dotyku ${ }^{35}$. Poza tym wzrok i słuch postrzegano jako zmysły niezbęd-

${ }^{32}$ W. Bałus, Dotykanie wzrokiem. O pojęciu haptyczności w klasycznej nauce o sztuce, „Konteksty” 2019, nr 4, s. 202.

${ }^{33}$ M. Podgórski, Ucieczka od wizualności i jej społeczne konsekwencje. Fenomen estetyki haptycznej, Poznań 2011, s. 18.

${ }^{34}$ Arystoteles, O duszy, przeł. P. Siwek, Warszawa 1992.

${ }^{35}$ Odnosząc się do wiedzy z zakresu biologii, trzeba stwierdzić, iż nie mamy tak wysokiej wrażliwości tzw. zmysłów niższych jak inne gatunki. Człowiek nie wykształcił takich zmysłów jak magnetyczny, wibracyjny czy elektryczny, choć badacze wymieniają też wiele dodatkowych zmysłów u ludzi, m.in. propriocepcję, nocycepcję, termocepcję, zmysł równowagi, chemoreceptory czy magnetorecepcję. Ciekawym zjawiskiem jest też doświadczanie przez niektórych ludzi tzw. synestezji - stanu, w którym doświadczenia jednego zmysłu (np. wzroku) wywołują doświadczenia charakterystyczne dla innych zmysłów. Szerzej na 
ne do przetrwania ${ }^{36}$. Myśl klasyczna postrzegała sztukę jako narzędzie duchowego oczyszczenia. Zmysł dotyku, jako ten dotyczący ciała i cielesności, przez całe wieki był traktowany jako ,gorszy”, przyziemny, niski. Bernard z Clairvaux głosił tezę o wyższości piękna wewnętrznego, a św. Tomasz z Akwinu przeciwstawiał przeżycie estetyczne „zwykłemu postrzeganiu i uwarunkowanym biologicznie czynnościom" ${ }^{37}$. W Iconologii Cesare Ripy ${ }^{38}$ z 1593 roku po raz pierwszy pojawiło się natomiast stwierdzenie, że dotyk nie musi być przyjemny - może bowiem wiązać się także z bólem. Dla Hegla jedynie wzrok zasługiwał na miano najszlachetniejszego ze zmysłów - jako zmysł duchowy i intelektualny, czyli pozwalajacy na zachowanie dystansu poprzez obserwację z pewnej odległości. Hegel określa zmysły wzroku i słuchu jako „teoretyczne” - w etymologii greckiego słowa theoria mamy odwołanie właśnie do sfery wizualnej. Greckie słowo háptein oznacza natomiast: 'złapać', 'przymocować', 'wiązać', co sugeruje fizyczny kontakt z przedmiotem.

Za początek uprzywilejowania zmysłów niższych można uznać osiemnastowieczne rozważania Aleksandra Baumgartena, który jako pierwszy utożsamia poznanie zmysłowe z poznaniem piękna, tworząc tym samym tak bliskie nam obecnie pojęcie ,estetyki” ${ }^{39}$. Zmysły stawały się coraz częstszymi przedmiotami rozważań i niekoniecznie ograniczały się do samego wzroku, postrzegania - wciąż jednak dzielono je na te wyższe i te pierwotne. Krytykę nobilitacji zmysłu wzroku spotkamy u osiemnastowiecznego filozofa Maine de Birana. Twierdził on, że dotyk jest zmysłem, który umożliwia nam bezpośredni kontakt ze światem. Dotyku nie da się oszukać - reinterpretuje on wrażenie wywołane zderzeniem z rzeczywistym obiektem ${ }^{40}$. Podobne poglądy miał wspomniany już filozof Johann Gottfried Herder, który mówił o zmyśle wzroku: „Zmysł wzroku dostarczy nam [...] większość idei dotyczących powierzchni rzeczy, a zatem większość przesądów: za jego to sprawą niebo

ten temat piszą: M. Koton-Czarnecka, Zmysty zwierzat sq niesamowite. Jak postrzegaja świat?, „National Geographic Polska” 25.02.2020, https://www.national-geographic.pl/artykul/zmyslowa-ostrosc (dostęp: 8.03.2020); Człowiek posiada znacznie więcej niż 5 zmystów, 16.06.2016, https://joemonster.org/art/36446, źródło anglojęzyczne: D. Hiskey, Humans have a lot more than five senses, 16.07.2010, http://www.todayifoundout.com/index.php/2010/07/ humans-have-a-lot-more-than-five-senses/ (dostęp: 3.08.2020); A. Mączyńska-Frydryszek, M. Jaskólska-Klaus, T. Maruszewski, Psychofizjologia widzenia, red. R. Bartel, Poznań 2001.

${ }^{36}$ W. Tatarkiewicz, Dzieje sześciu pojęć: sztuka, piękno, forma, twórczość, odtwórczość, przeżycie estetyczne, red. E. Nowakowska, Warszawa 1975.

${ }^{37}$ Ibidem, s. 401.

${ }^{38}$ C. Ripa, Ikonologia, Kraków 2013.

${ }^{39}$ A.G. Baumgarten, Metafizyka, przeł. i oprac. J. Surzyn, seria Biblioteka Europejska, Kęty 2012. Zob. też: P. Kozak, Wychować Boga. Estetyka antropologiczna Alexandra Gottlieba Baumgartena na tle myśli niemieckiej pierwszej połowy XVIII wieku, Warszawa 2013.

${ }^{40}$ Ibidem, s. 131. 
stawało się firmamentem, chmury - stadem baranów, księżyc - błyszcząca tarczą itd. Zdarza się powszechnie, że to, co widzimy tylko za pomocą wzroku, widzimy w sposób fałszywy, błędny" ${ }^{41}$. To on sparafrazował słynną myśl Kartezjusza w słowach: „Czuję siebie! Jestem!”, wyznaczając tym samym punkt centralny swoich refleksji estetycznych.

Dopiero w XX wieku, między innymi za sprawą rosnącego zainteresowania artystów, powstały teorie estetyczne akcentujące udział całej ludzkiej zmysłowości w doświadczeniu estetycznym i dzięki temu kwestionujące stereotypy towarzyszące zmysłowi dotyku ${ }^{42}$. Estetyk Karl Aschenbrenner ${ }^{43}$ dokonał klasyfikacji zmysłów, wedle której odczucia związane ze smakiem, z temperaturą i zapachem należą do tych niższego rzędu, będących jedynie tłem dla prawdziwego przeżycia estetycznego, zapewnianego nam przez wzrok i słuch. Odnosząc się do jego słów, Maria Gołaszewska w Estetyce pięciu zmysłów pisze: „Tu także należą doznania owych zmysłów «niższych»: zapachy, doznania dotykowe, smakowe, wrażenia somatyczne i kinetyczne, które - zależnie od charakteru - ułatwiają czy umożliwiają, albo znacznie utrudniają koncentrację na tym, co znajduje się na pierwszym planie naszej percepcji czy koncentracji intelektualnej" ${ }^{44}$. Jedna z takich teorii jest zapoczatkowana przez Johna Deweya, a rozwijana obecnie przez amerykańskiego filozofa Richarda Shustermana estetyka pragmatyczna. Z perspektywy pragmatycznej poniższe rozważania nad dotykowymi kategoriami mają na celu nie tylko uchwycenie funkcjonowania tego zmysłu w sztuce, lecz także wzbogacenie procesów powstawania i oddziaływania samej sztuki. Badacz proponuje nową dziedzinę wiedzy - „,somatoestetykę”, w założeniu obejmująca „krytyczne i mające na celu doskonalenie badania nad doświadczaniem i wykorzystywaniem ciała jako ośrodka zmysłowo-estetycznego wartościowania (aisthesis) i twórczej autokreacji”"

${ }^{41}$ Cytat przytoczony przez Krzysztofa Tkaczyka w tekście Johann Gottfried Herder. Sensualistyczny bunt wobec klasycznej estetyki, [w:] W kulturze dotyku? Dotyk i jego reprezentacje $w$ tekstach kultury, red. A. Łebkowska, Ł. Wróblewski, P. Badysiak, Kraków 2016, s. 20.

${ }^{42}$ Warto tu podkreślić, że w kulturach pozaeuropejskich ta kwestia wygląda inaczej: doświadczenie estetyczne jest ujmowane jako angażujące całość cielesnej egzystencji człowieka. Przykładem może być japońska ceremonia parzenia herbaty, w której oprócz walorów wizualnych i smakowych istotne są aspekty haptyczne (np. doznanie faktury naczynia wypełnionego naparem).

${ }^{43} \mathrm{~K}$. Aschenbrenner, Jak możliwa jest sztuka?, przeł. M. Gołaszewska, [w:] Eseje o pięknie. Problemy estetyki i teorii sztuki, red. K. Wilkoszewska, Warszawa-Kraków 1988; [także w:] Eidos sztuki, red. M. Gołaszewska, Kraków 1988.

${ }^{44}$ M. Gołaszewska, Estetyka pięciu zmystów, Warszawa-Kraków 1997, s. 117.

${ }^{45}$ R. Shusterman, Estetyka pragmatyczna. Żywe piękno i refleksja nad sztuka, red. nauk. A. Chmielewski, przeł. A. Chmielewski i in., Wrocław 1998, s. 138. 


\section{Dotyk sceny, czyli odbiorca w uścisku performansu i spektaklu}

Jak słusznie zauważa współczesna badaczka performansu: „Ograniczając się jedynie do zmysłu wzroku, umniejszamy nasze człowieczeństwo. $\mathrm{W}$ poprzek tej powszechnej tendencji występuje dotyk - jako interakcja z rzeczywistościa [...], jako pragnienie kontaktu z realną rzeczywistościa i pominięcie powszechnej retoryki iluzji, wreszcie jako wyjście z usankcjonowanych społecznie reguł istnienia" ${ }^{46}$. Nazywa wzrok „zmysłem dystansu i narzędziem iluzji” ${ }^{47}$, dotyk natomiast postrzega jako metodę odejścia od iluzoryczności i „wejścia w bezpośredniość, a przede wszystkim wzajemność" 48 .

Klasyczny już performans najbardziej znanej i opisanej artystki tej sztuki, Mariny Abramović, będzie najlepszą ilustracją tych słów. Imponderabilia z 1977 roku to performans, którego koncepcja zakładała mocne skrócenie dystansu i wejście w bezpośredni kontakt z odbiorcą. Podstawą jego stworzenia była bliska relacja artystów - Mariny oraz jej życiowego i artystycznego partnera Uwego Laysiepena, nazywanego Ulayem. Przez dekadę stworzyli oni serię prac ikonicznych dla historii body artu. Głównym celem ich życiowo-artystycznego związku było eksplorowanie cielesności, w tym zanegowanie podziału na dwie płcie. W performansie Imponderabilia Ulay i Marina stali nago po przeciwległych stronach futryny w wąskim przejściu w przestrzeni Muzeum Galleria d'Arte Moderna w Bolonii, a pomiędzy nimi musieli przeciskać się widzowie, dokonując równocześnie wyboru, do kogo odwrócić się twarzą. Luka między ich ciałami została określona jako metafora kanału rodnego. Performans miał trwać trzy godziny, ale został przerwany przez policję po zaledwie dziewięćdziesięciu minutach, ponieważ uznano go za obsceniczny. Artyści specjalnie przekraczali granicę komfortu, żeby pokazać, jak bardzo współczesna kultura powoduje, że nie jesteśmy przygotowani na kontakt z drugim człowiekiem, oraz jak bardzo stabuizowane są nagość i intymność. Performans mocno skracał dystans pomiędzy twórca, dziełem a odbiorca, angażujacc silnie zmysły, w tym zwłaszcza „prowokujacc" zmysł dotyku.

Artystka od lat poddaje swoje ciało ekstremalnym doświadczeniom i wprowadza widzów/uczestników swoich dzieł w skrajne stany emocjonalne. Konsekwentnie redefiniuje to, czym jest i czym może być sztuka współczesna, a jej narzędziem jest własne ciało, którego granice i wytrzymałość bezwzględnie testuje. Przeprowadza na nim artystyczne eksperymenty związane z bólem, obrzydzeniem, reakcjami na ingerencje fizyczne (np. Rytm 10,

${ }^{46}$ S. Bąk, Dotyk w performansie, [w:] W kulturze dotyku? Dotyk i jego reprezentacje..., ed. cit., s. 305 .

${ }^{47}$ Ibidem, s. 304.

${ }^{48}$ Ibidem, s. 306. 
1973; Rytm 5, 1974; Rytm 0, 1974; Thomas Lips / Lips of Thomas, 1975; Art Must Be Beautiful / Artist Must Be Beautiful, 1975; Relacje w przestrzeni, 1976; Batkański barok, 1997).

Jednym z bardziej brutalnych performansów, na który się zdecydowała, był Thomas Lips. Doszło do niego w 1975 roku w Galerie Krinzinger w Innsbrucku, na zaproszenie galerii. Tytuł akcji artystka zaczerpnęła od imienia i nazwiska jednego ze swoich kochanków. Podczas trwającego dwie godziny performansu najpierw spożyła kilogram miodu srebrną łyżka, następnie wypiła litr czerwonego wina wprost z kryształowego kielicha, a po wypiciu rozbiła kieliszek. Czynności te wykonywała w wolnym tempie. Następnie wycięła sobie na rękach szramy, a na brzuchu pięcioramienną gwiazdę. Naga, biczowała się, aż tryskała z niej krew. Nie przestawała aż do momentu, kiedy przestała odczuwać ból. Opowiadała, że czuła się, jakby przekroczyła ścianę cierpienia. Następnie położyła się na podłodze, na krzyżu zbudowanym z bloków lodu. Wówczas opuszczono na nią grzejnik, wcześniej podwieszony drutami pod sufitem. Za przyczyną ciepła, które on emitował, pocięty brzuch kobiety nie przestawał krwawić. Ona sama leżała nieruchomo i oddychała najwolniej, jak umiała, poddając tylną część ciała działaniu przenikliwego zimna, a przednią - przeszywającego ciepła. Jak zauważa Erika Fischer-Lichte: „W tym performansie chodzi o działania autoreferencyjne, ustanawiające specyficzna rzeczywistość (do czego, nawiasem mówiąc, zawsze prowadzą konkretne działania). Dzięki temu moga one spowodować przemianę artystki i uczestników jej performansu, niezależnie od tego, jaką postać przybierze owa przemiana. Jak jednak zastosować w tym przypadku kryterium fortunności bądź niefortunności? Nie ma wątpliwości, że artystka zjadła zbyt wiele miodu i wypiła zbyt wiele wina oraz faktycznie poraniła swoje ciało, używając żyletki i pejcza. Nie ma też wątpliwości, że kres jej cierpieniom położyli widzowie, którzy podnieśli ją z brył lodu i wynieśli z sali. Czy jednak tym samym performans się udał?" 49 . Wydaje się, że na to pytanie można odpowiedzieć twierdząco, gdyż odbiorcy weszli z artystką w interakcję w ramie działania, którą wyznaczyła im instytucja (galeria sztuki), choć jednocześnie ja przekroczyli. Performerka nie poddawała się biernie skierowanej przeciw niej przemocy, przynoszącej ból i cierpienie, lecz za każdym razem aktywnie jej doświadczała. A cielesność, zmysłowość, ból stały się głównymi składnikami-aktorami dramaturgii tego performansu.

Abramović jest bohaterką nagrodzonego przez publiczność Berlinale amerykańskiego dokumentu Matthew Akersa, pokazującego jej życie

${ }^{49}$ E. Fischer-Lichte, Estetyka performatywności, przeł. M. Borowski, M. Sugiera, Kraków 2008, s. 34. 
i twórczość przez pryzmat jednej z najbardziej spektakularnych akcji artystycznych, która przeprowadziła podczas wielkiej retrospektywy swojej twórczości w nowojorskim Museum of Modern Art w 2010 roku. Przez trzy miesiace na kilka godzin dziennie siadała bez ruchu na krześle w galeryjnej sali. Przysiadali się do niej zwiedzający. Opisywane przez nich później doświadczenie okazało się trudną próbą ciała i emocji. W wyniku tej swoistej, pozbawionej słów psychoterapii pomiędzy artystką a widzami tworzyły się spontaniczne relacje - wiele osób, patrząc jej w oczy, płakało. Co ciekawe, dramaturgia tego doświadczenia artystycznego, a jednocześnie głęboko osobistego, rozgrywała się przede wszystkim na poziomie zmysłu wzroku ${ }^{50}$. „Cielesna współobecność wykonawców i widzów umożliwia przedstawienie, to ona je stanowi. Żeby przedstawienie mogło się odbyć, wykonawcy i widzowie muszą się zebrać na określony czas w określonym miejscu i razem coś przedsięwziąć. [...] Cielesna współobecność oznacza raczej relację między podmiotami. Widzowie to bowiem równorzędni uczestnicy, którzy biorąc udział w grze, powołują do istnienia przedstawienie dzięki swojej fizycznej obecności, percepcji, a także dzięki swoim reakcjom. Tym samym przedstawienie powstaje jako wynik interakcji między aktorami i widzami” ${ }^{51}$. Najważniejsze jest to, co wydarza się między uczestnikami, rodzaj „duchowej infekcji”, która się między nimi rozprzestrzenia, to, co się wydarza, współprzeżywanie - zarówno na poziomie zmysłowym, jak i afektywnym. Widz nie tylko obserwuje, w jaki sposób dochodzi do zamiany ról między publicznością a aktorami, budowania i niszczenia wspólnoty czy tworzenia bliskości i dystansu, lecz także doświadcza tych procesów na własnej skórze jako uczestnik przedstawienia.

„Dotyk sceny” może się przejawiać także w inny sposób. Eksperyment na poziomie zmysłowego odbioru spektaklu stał się punktem wyjścia do stworzenia dwóch innych ciekawych projektów przez Adama Ziajskiego reżysera i dyrektora Centrum Rezydencji Teatralnej Scena Robocza w Poznaniu. Nie mów nikomu ${ }^{52}$ i Spójrz na mnie ${ }^{53}$ to spektakle, których dra-

${ }^{50}$ Film dokumentalny: Marina Abramović: Artystka obecna / Marina Abramović: The Artist Is Present, USA 2012 / 106', reżyseria: Matthew Akers, Jeff Dupre.

${ }^{51}$ E. Fischer-Lichte, op. cit., s. 46-47.

${ }^{52}$ Nie mów nikomu, scenariusz i reżyseria: A. Ziajski, prapremiera: 25.11.2016, Centrum Rezydencji Teatralnej Scena Robocza, wideo: kolektyw wooom visuals, dźwięk: M. Frycz, kostiumy i scenografia: Grupa Mixer, obsada: J. Frąckowiak, Z. Mądra, K. Mądry, P. Nowak, D. Mroczek-Dąbrowska, A.M. Turek, A. Ziajski.

${ }^{53}$ Spójrz na mnie, reżyseria i scenariusz (na podstawie historii bohaterów): A. Ziajski, prapremiera: 23.02.2018, Teatr Ślaski im. Stanisława Wyspiańskiego w Katowicach, premiera poznańska: w ramach cyklu Teatr Powszechny w CK Zamek, scenografia i kostiumy: Grupa Mixer, wizualizacje: F. Czernow, audiodeskrypcja: I. Mrochen, realizacja dźwięku: M. Frycz, M. Lichtański, realizacja światła: T. Wustrau, realizacja projekcji: B. Koźbiał, asystent reżyse- 
maturgia opiera się na grze z naszymi przyzwyczajeniami percepcyjnymi. Spektakl Nie mów nikomu powstał jako manifest wobec zdegenerowania języka oraz obecnych w nim strategii wykluczania i przemocy. Ziajski tak tłumaczy jego genezę: „Jestem głęboko przejęty i zawstydzony stanem językowej wspólnoty. Mam nieodparte wrażenie, że używanie słów i ich znaczeń z coraz większą intensywnością staje się narzędziem zbiorowej konfrontacji, walki wszystkich ze wszystkimi. [...] Do realizacji spektaklu zaprosiłem osoby niesłyszące. Wśród nich jest również jedna osoba niewidoma. $\mathrm{Na}$ początku czułem się zawstydzony tym, jak reaguję i co o nich wiem. Dzisiaj chciałbym krzyknąć: wybieram milczenie! Ale jak tu wykrzyczeć takie wyznanie?" ${ }^{4}$. Reżyser przede wszystkim musiał spróbować wyłączyć jeden ze zmysłów - uznawany przez całe wieki jako jeden z dwóch tzw. zmysłów wyższych słuch - aby wejść w świat aktorów-bohaterów. Osoby niesłyszące czy niedosłyszące mogą poczuć się na tym przedstawieniu jako widzowie „docelowi”, a na co dzień pełnosprawni - na swój sposób upośledzeni w jego odbiorze (świadczy o tym już sam sposób gry - całość jest grana w języku migowym z polskimi napisami, publiczność bez zaburzeń słuchu siedzi w wygłuszających słuchawkach). Autentyczności całemu doświadczeniu dodaje to, iż projekt opiera się na osobistym doświadczeniu osób niesłyszących grających w spektaklu oraz na reportażu Anny Goc Gtusza, który opowiada o trudnej codzienności osób głuchych i niedosłyszących w Polsce ${ }^{55}$. Ziajski dostrzega też aspekt estetyczny - język migowy jest trójwymiarowy, a przez to niezwykle choreograficzny. Reżyser opowiada o izolacji komunikacyjnej, używając bardzo wyrazistych, a zarazem prostych środków scenicznych. Odbiorcy spektaklu dostają wygłuszające dźwięk słuchawki, gdyż ze sceny często rozlega się nieznośny hałas, skierowany do niesłyszących aktorów, aby poprzez drgania fal dźwiękowych mogli „poczuć” dźwięk. Reżyser jest tu zarazem scenicznym wykonawcą (oczywiste jest tu skojarzenie z Tadeuszem Kantorem). Kieruje dźwiękiem i obrazem, kreując spontanicznie,

ra: M. Markiewicz, przewodniczka aktorów niewidomych: A. Fielek, inspicjent: A. Kandziora, producent wykonawczy: M. Długowska-Błach, kierownik techniczny: M. Rokita, projekt plakatu: J. Lemańska, zdjęcia: P. Jendroska, autorka zapachu ciemności: A. Cacha (Olfaktura), obsada: M. Bąk, B. Błaszczyński, G. Kania, A. Machoń, M. Piotrowski, A. Słowik i pies Kora (do lutego 2020) / pies Asari (od lutego 2020), M. Wierzbicki, A. Ziajski oraz M. Frycz, muzyka na żywo i I. Mrochen / M. Markiewicz, audiodeskrypcja na żywo. Znamienne jest, jak wiele osób o różnych specjalizacjach zawodowych było zaangażowanych w powstanie tego projektu; dlatego wymieniam je tu wszystkie.

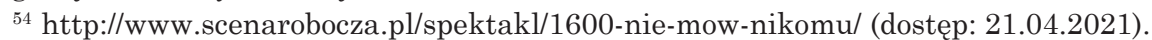

${ }^{55}$ Gtusza, reż. A. Goc, „Tygodnik Powszechny” 22.08.2016, https://www.tygodnikpowszechny.pl/glusza-35169 (dostęp: 21.04.2021). Reportaż ma wersję do czytania i do słuchania - w nagraniu zamieszczonym na stronie czasopisma czyta go Anna Dymna, a przekłada na język migowy Magdalena Sipowicz. 
improwizująco nastrój i rytm tego spektaklu. Porusza antena, co powoduje gwałtowne zmiany brzmienia hałasu, a w ślad za dźwiękami idą projekcje monochromatycznych, niebiesko-białych plam oraz linii, rzucane na boczne ściany, które są zbieżne w tonacji i natężeniu z hałasem. Na tylnej ścianie pojawia się napis mówiący o tym, że na pewno nie zrozumiemy kogoś, kto ze ściszonego telewizora mówi do nas po węgiersku. A to jest sytuacja ludzi niesłyszących. Na scenie gra pięcioro niesłyszących wykonawców, przyodzianych w jednolite białe ubiory. Najpierw wykonują oni gimnastykę dłoni przygotowanie do użycia języka migowego. Kolejni bohaterowie podchodza do frontu sceny, zanurzają ręce w szklanych bańkach (każdej z proszkiem w innym kolorze), barwią swoje ciała i ubrania i zaczynają opowiadać swoje historie. Ich narracja nie jest do słuchania, lecz do oglądania - widzimy migające dłonie i tłumaczenie na ekranie. Historia dwójki bohaterów jest szczególna: pan Kazio jest głuchoniemy i niewidomy, a jego partnerka życiowa, pani Zosia, porozumiewa się z nim, kreśląc palcem na jego dłoni znaki specjalnego języka dla głuchoniemych niewidomych. Dotyk stał się dla nich podstawowym zmysłem komunikacji i - dla niego - jakiegokolwiek kontaktu ze światem zewnętrznym ${ }^{56}$.

Z kolei w Spójrz na mnie na pierwszym planie jest warstwa dźwiękowa przedstawienia, gdyż odwołuje się ono do doświadczeń osób niewidzących i słabowidzących. Ale pojawia się też próba uruchomienia zmysłu węchu Aleksandra Cacha z Olfaktury podjęła próbę stworzenia zapachu ciemności. Twórcy zadbali o jak najbardziej multisensoryczny odbiór, nie zaniedbując tych sprawnie działających zmysłów. Sam plakat do spektaklu został zaprojektowany tak, że na białym tle w samym jego centrum wytłoczono tytuł zapisany alfabetem Braille'a. Ziajski przez kilka miesięcy przeprowadzał wywiady z osobami niedowidzącymi, ociemniałymi i niewidomymi. Na tej podstawie powstał scenariusz. Spośród tych osób wybrał bohaterów spektaklu, reportażu teatralnego, którzy występują na scenie obok aktorów Teatru Śląskiego. Przedstawił na scenie świat, którego nie da się zobaczyć. Spektakl każdorazowo jest grany z audiodeskrypcja, w związku z czym liczba miejsc jest ograniczona przez liczbę słuchawek. Pięcioro niewidomych bohaterów opowiada o swoim doświadczeniu bycia niewidzialnymi, osamotnionymi i wyizolowanymi przez to, że są niewidomi. To teatr dokumentalny, w którym realne osoby opowiadają o swoich autentycznych doświadczeniach. O swoistej stygmatyzacji osób niewidzących w symboliczny sposób mówią już pierwsze sceny spektaklu, w których zostają przywołane fragmenty Księgi Rodzaju dotyczące stworzenia świata. Odczytuje je syntezator mowy cha-

${ }^{56} \mathrm{~W}$ opisie spektaklu wykorzystano fragmenty recenzji J. Tyszki Zza szyby po wegiersku, 21.12.2016, https://teatralny.pl/recenzje/zza-szyby-po-wegiersku, 1802.html (dostęp: 21.04.2021). 
rakterystyczny dla urządzeń lektorskich, którymi posługują się niewidomi. Cytaty z Księgi Rodzaju sa przeplatane kolejnymi opowieściami pięciorga bohaterów spektaklu, niewidomych bądź słabowidzących. Choć jesteśmy w stanie rozróżnić ich głosy, to jednak nie przypiszemy tej mowy do konkretnych ciał, gdyż kostiumy i scenografia zaprojektowane przez Grupę Mixer dążą do unifikacji postaci i przestrzeni. Wszyscy aktorzy noszą te same białe kaftany, ich twarze osłaniają mocno przylegające maski, a rzutowane na ściany i podłogę wizualizacje (proste figury geometryczne, kratki, koła, barwne plamy i krzywe linie) powoduja, że ciała aktorów całkowicie zlewają się z przestrzenia. „Ta «niewidoczność» i anonimowość bohaterów, którą uzyskuje się dzięki efektom wizualnym, jest zamierzona i - tłumaczy Ziajski - ma odnosić się do sytuacji «niewidzialności» osób niewidomych w społeczeństwie" ${ }^{27}$. Całe przedstawienie rozgrywa się w mroku, a momentami w całkowitej ciemności - to zmusza widzów do przyjęcia takiego modelu percepcji, który wyklucza dominację wrażeń wzrokowych. Przeciwstawione im doznania akustyczne potęguje użycie słuchawek - płynące z nich dźwięki to zarówno muzyka, szumy, jak i głosy aktorów ${ }^{58}$.

W ten sposób kształtuje się estetyka zmysłów; smak, węch i dotyk zyskują wreszcie należne im miejsce. To działania często na styku różnych sztuk - działań performatywnych, teatralnych, z zakresu sztuk wizualnych i innych. Olfaktologia coraz mocniej wkracza do działań artystycznych, a powszechny okulocentryzm zostaje poddany krytyce. Teatr, podobnie jak sfera projektowania i sztuk wizualnych, jest doskonałym polem do działania w obszarze sensoryki. Zmysły budują naszą historię, pamięć, emocjonalność. Za ich sprawą możliwe staja się przekraczanie dominującego porządku i przywrócenie communitas, uruchamiającego wszystkie zmysły.

\section{Dotyk ekranu, czyli immersja zmysłów}

Immersja to pojęcie z zakresu fizyki, pochodzące od łacińskiego słowa immergo - 'zanurzam'. W ściśle naukowym sensie odnosi się do metody stosowanej w mikroskopii polegającej na zwiększeniu zdolności rozdzielczej mikroskopu optycznego poprzez ,wypełnienie przestrzeni między przedmiotem a pierwszą soczewką obiektywu mikroskopu przezroczysta cieczą", a w astronomii oznacza „wejście jednego ciała niebieskiego w cień drugiego"59. Jednak

${ }^{57} \mathrm{~W}$ opisie spektaklu wykorzystano fragmenty recenzji M. Figzał-Janikowskiej Sceny widzialności, 21.03.2018, https://teatralny.pl/recenzje/sfery-widzialnosci,2313.html (dostęp: 22.04.2021).

${ }^{58}$ M. Figzał-Janikowska, op. cit.

${ }^{59}$ https://sjp.pwn.pl/sjp/immersja;2561260 (dostęp: 20.03.2021). 
współcześnie to pojęcie coraz częściej pojawia się w kontekście technologii i mediów elektronicznych i jest tłumaczone jako proces „zanurzania” czy „pochłaniania” odbiorcy przez rzeczywistość elektroniczna, przez co dochodzi do „zanurzenia zmysłów”. Zwłaszcza sposób percepcji gier komputerowych jest opisywany w kontekście ich immersyjnego odbioru. Gracz znajduje się w pozycji tego, który faktycznie działa na gruncie świata wirtualnego, przy czym bariery fizjologiczne - brak cielesnego bycia w owym świecie - nie maja wpływu na jego zaangażowanie. Światy wirtualne projektowane przez twórców gier komputerowych umożliwiają zanurzenie się w nie. Gracze nadal mają świadomość, że mają do czynienia z medium, które tylko reprezentuje świat, nie tworzy go realnie ${ }^{60}$.

Okres pandemii silnie wpłyną na eksplorację tej właśnie przestrzeni wirtualnego kontaktu między twórca a odbiorca. Sa to przede wszystkim projekty bardzo oczywiste i od lat już obecne w praktyce wielu instytucji i działaczy kultury (choć na dużo mniejszą skalę niż obecnie), takie jak zapisy spektakli udostępniane online czy wirtualne wystawy na stronie muzeum lub galerii. Jednak niektóre z tych działań przybrały immersyjna formę, bardzo mocno angażując w swój przebieg publiczność. Przykładem są tu spektakle Teatru Usta Usta Republika Ambasada $2.0^{61}$ i 777 online ${ }^{62}$, które miały premierę na platformie Zoom. Nie są one zapisami filmowymi udostępnionymi widzom ani nawet prezentacjami w czasie rzeczywistym, ale interaktywną formą sztuk performatywnych, w której od widza wymaga się aktywności i zaangażowania. Dwa jubileuszowe spektakle (zespół w 2020 roku obchodził dwudziestolecie istnienia) potwierdziły wieloletnia strategię twórcza zespołu, który eksploruje nietypowe przestrzenie i szuka nieoczywistych form kontaktu z widzem.

Choć spektakl Ambasada z 2006 roku pierwotnie wymagał olbrzymiego zaangażowania - od internetowej rejestracji, przez wizytę w jednym z klubów, po jazdę samochodem do wieży zegarowej poznańskiego Zamku i wędrówkę po nim w późnych godzinach nocnych, to ten z 2020 roku wcale mu nie ustępował. To przedstawienie z gatunku site-specific theatre, choć na poziomie eksperymentów teatralnych próby grania w internecie pojawiały się już wcześniej (pierwsza premiera internetowa odbyła się 12 grudnia

${ }^{60}$ K. Prajzner, Tekst jako świat i gra. Modele narracyjności w kulturze wspótczesnej, Łódź 2009, s. 26.

${ }^{61}$ Ambasada 2.0, Teatr Usta Usta Republika, spektakl online w aplikacji Zoom, premiera: 22-24.05.2020, reżyseria: W. Wiński, scenariusz: E. Kaczmarek, K. Macejko, W. Wiński, http://www.ustausta.pl/ambasada-2/ (dostęp: 20.04.2021).

${ }^{62} 777$ online, Teatr Usta Usta Republika, spektakl online w aplikacji Zoom, premiera: 16.10.2020, reżyseria: W. Wiński, scenariusz: E. Kaczmarek, K. Macejko, W. Wiński, http:// www.ustausta.pl/777-online/ (dostęp: 20.04.2021).

247 Szorstki i chropowaty dotyk - o dramaturgii zmysłów 
1993 roku za pośrednictwem IRC - Internet Relay Chat, HamNet ${ }^{63}$ w adaptacji Stuarta Harrisa rozgrywał się na czacie i uczestniczyli w nim na żywo zarówno aktorzy, jak i zwykli internauci; od 2011 roku jest też realizowany projekt wirtualnej sceny przy użyciu social mediów przez Maxim Gorki Theater, zapoczątkowany premiera spektaklu Effi Briest). Choć kontakt na linii widzowie-aktorzy jest mocno zapośredniczony, to jednak jest jak najbardziej żywy, silny, angażujacy i na swój sposób bezpośredni. Ambasada 2.0 nie jest bowiem jedynie odtworzeniem rejestracji spektaklu-zdarzenia, czyli przedstawieniem mediatyzowanym, ale rozgrywanym przy udziale widzów w czasie rzeczywistym, tyle że w wirtualnej przestrzeni.

Paradoksalnie wydaje się zatem, że mimo technologicznego zapośredniczenia zostaje utrzymana $\mathrm{w}$ mocy kategoria liveness (nażywośćc4) i mimo dystansu przestrzennego zostaje zachowana autozwrotność komunikacji. Aktorzy grają w czasie rzeczywistym, sa tu i teraz, choć po drugiej stronie ekranu. Ponadto - co mocno wykorzystują twórcy z grupy Usta Usta Republika - mają szansę wchodzić w interakcje, dostrzec w okienkach widzów, zadać im pytanie lub o coś poprosić. Małgorzata Sugiera zauważa, iż współcześnie to pojęcie bardzo rozszerzyło swoje znaczenie i odwołuje się do pojęć „nażywość online” oraz „nażywość grupowa”. Badaczka zwraca uwagę na obecną w obu wypadkach „nieprzerwana, technologicznie zapośredniczoną (przez Internet czy telefonię komórkowa) współobecność z innymi w tym samym czasie, choć nie w tym samym miejscu. Co istotne, tak poszerzona definicja nażywości obejmuje także interakcje z maszynami, które jako część pętli feedbacku zyskują wrażenie «życia» i sprawczości. [...] dokonało się w tej definicji kolejne istotne przesunięcie: już nie ontologia żywych ciał i nie relacja między mediami a technologiami okazuje się źródłem nażywości, lecz afektywne doświadczenie uczestnika wydarzenia, i to niezależnie od stopnia oraz sposobu technologicznego zapośredniczenia”"5. Kolejni badacze tego pojęcia idą jeszcze dalej, proponując zamiast binarnej pary podejście komplementarne, w którym światy realny i wirtualny nie konkurują ze sobą, lecz się uzupełniają.

Widz staje się aktywnym współkreatorem całego wydarzenia. Jego dostęp do przedstawienia warunkują zaplecze i umiejętności technologiczne - wypełnienie formularza na stronie internetowej spektaklu ${ }^{66}$, wymiana

${ }^{63} \mathrm{O}$ tym projekcie pisze T. Kubikowski. Zob. Teatr w sieci, [w:] Kultura i sztuka u progu XXI wieku, red. S. Krzemień-Ojak, Białystok 1997.

${ }^{64}$ P. Auslander, Na żywo czy..., przeł. M. Borowski, M. Sugiera, „Didaskalia. Gazeta Teatralna" 2012, nr 107.

${ }^{65}$ M. Sugiera, Nażywość, [w:] Performatyka: terytoria, red. E. Bal, D. Kosiński, Kraków 2017 , s. $146-147$.

${ }^{66} \mathrm{http} / / / \mathrm{www}$. tlustalangusta.pl/ambasada (dostęp: 18.05.2020). 
korespondencji mailowej z Pierwszym Sekretarzem Ambasady, zainstalowanie aplikacji Zoom. Do zainteresowanego udziałem odbiorcy są adresowane liczne techniczne wskazówki: ,zainstaluj na swoim laptopie lub komputerze aplikację ZOOM - odradzamy korzystanie z telefonu komórkowego”; „zadbaj o szybkość i stabilność Twojego połączenia internetowego - nie chcielibyśmy się nawzajem znienacka stracić, nieprawdaż?”; „na czas spotkania zapewnij sobie miejsce i spokój, aby nikt Ci nie utrudniał wizyty - uczestnictwo postronnych osób jest niewskazane”; „zaopatrz się w słuchawki (z mikrofonem), aby nic nie umknęło Twojej uwadze”; „poświęć kilka minut, aby skonfigurować komunikator ZOOM - spójrz na krótki poradnik przygotowany przez naszą Administrację". Wśród tych technicznych wskazówek znalazła się i taka, która mówiła: „Zaopatrz się w małą przekąskę oraz có́ słodkiego (batonik, ciastko, czekoladka)”. Okazuje się później, że warto było mieć tę przekąskę przygotowaną, bo stała się częścią artystycznych działań. Stajemy się współuczestnikami na wielu poziomach spotkania. Poziom techniczny jest tu bazą niezbędną do nawiązania się relacji. Następuje wymiana mailowej korespondencji z Pierwszym Sekretarzem, później zostaje przygotowane miejsce spotkania (ze słodka przekaska włącznie), potem jest wejście w kontakt „na żywo” w wirtualnym środowisku internetu, a jednocześnie wejście dzięki tym narzędziom w realną (choć wirtualna) przestrzeń poznańskiego Zamku. Do tego dochodzą wcześniejsze doświadczenia samego odbiorcy teatralnego: czy widział jakieś inne spektakle zespołu, czy uczestniczył w pierwszej Ambasadzie z 2006 roku, czy interaktywność w kulturze jest dla niego czymś znanym i oswojonym, czy też zupełnym novum. Dramaturgia spektaklu zasadza się na sprzężeniu zmysłów realnych $\mathrm{z}$ ich wirtualnym przetworzeniem. Twórcy staja przed nowymi problemami - od perfekcyjnego opanowania medium przekazu, przez nieco bardziej filmowe niż teatralne kwestie, sposób kadrowania siebie i przestrzeni czy zastosowanie natężenia głosu, po reakcje na zachowania i wypowiedzi samych widzów-współuczestników (czy udzielać im wskazówek technicznych podczas trwania spektaklu, jak zareagować na to, że ktoś w tym czasie piecze ciasto czy karmi dziecko). Te niepokoje i trudy realizacyjne świetnie oddaje Marcin Głowiński, jeden z twórców projektu: „Jest sieć czy nie ma sieci, oto jest teatr w czasach pandemii. Siedemnaście osób na Zoomie. Zaraz zaczynamy, nie, to nie jest spektakl, to jest dziesięć rozpoczynających się co 15 minut spektakli, dla dziesięciu grup widzów [...]. Gdzieś na granicy Niemiec i Luksemburga siedzi reżyser, półelektronowy mózg, WW"67. A zespół na swoim profilu facebookowym po premierze dodaje: „Graliśmy na

${ }^{67} \mathrm{https}: / /$ www.facebook.com/photo.php?fbid=3462480057115219\&set=a.197707623 592495\&type=3\&theater (dostęp: 15.06.2020). 
żywo, obserwując Wasze reakcje i słuchając Waszych odpowiedzi. [...] Być może teatr w sieci oddziela nas ekranem, ale skraca dystanse" ${ }^{68}$. W trakcie trwania spektaklu uczestnictwo ma cały czas charakter interaktywny: widzowie wędruja po korytarzach i salach zamkowych, wypełniają ankiety, a ich odpowiedzi sa wykorzystywane $\mathrm{w}$ dalszych działaniach i istotne dla przyznania końcowego azylu w ambasadzie.

W 777 online uczestnictwo publiczności przebiega podobnie - wymaga zaangażowania, interakcji, nieustannej czujności po obu stronach monitora i słuchawek. Spektakl premierowy z 2007 roku, grany na parkingu pod placem Wolności, w założeniu także wymagał zaangażowania publiczności. Najnowsza „zoomowa” realizacja wnosi do sfery odbioru nowy aspekt - dużą intymność spotkania z artystami. Po zalogowaniu na platformę Zoom widz przechodzi na stronę spektaklu, otrzymuje przydomek (odwołujący się do kolorów, np. Czerwona, Biały, Niebieska) i rozpoczyna podróż po wirtualnych pokojach (nazwanych: wiedza, wiara, miłość, zazdrość, zbrodnia czy zdrowie). Widzowie są przełączani do różnych pokoi, towarzyszą im w tym inni widzowie-uczestnicy, a zdarza się, że czasem są zupełnie sami - twarzą w twarz (ekran w ekran) z aktorem. Zoom odbiera, co prawda, możliwość polisensorycznej percepcji (przez ekran nie posmakujemy, nie powąchamy, nie dotkniemy), ale artyści nieustannie odwołują się do tych pozostałych zmysłów (np. częstuja kawą herbatą lub czymś mocniejszym), wpływając na wyobraźnię odbiorcy.

Immersywność staje się nowym stylem odbioru, częścią procesu wypierania strategii percepcyjnych przez partycypacyjne. Krzysztof Maj proponuje następująca definicję: „Pojęciem, które uwspólnia Coleridge’owskie gorliwe zawieszenie niewiary z Tolkienowską wiarą w pozytywny wymiar eskapizmu i Suvinowskim przekonaniem o wyobcowującej sile światotwórstwa, jest i m e r s j a - dosłownie oznaczająca zanurzenie, zagłębienie czy pogrążenie, jednak metaforycznie opisująca pewien szczególny akt odbioru, polegający na zatraceniu się w świecie narracji”'69. Podkreśla za innymi badaczami tego zjawiska, że immersywny odbiór to taki, w którym użytkownik zanurza się w przestrzeni wzrokowej, dźwiękowej i dotykowej, właściwej dla danego środowiska tak mocno, że stwarza się poczucie obecności w wirtualnym świecie, wymykające się fizyczności. Następuje zredukowanie dystansu. Immersja jest transmedialna i polisensoryczna, a jej odbiór można określić mianem światoodczucia, czyli takim partycypowaniem w fikcyjnym świecie, które obejmuje cały zespół charakterystycznych dla niego cech i towarzyszy

\footnotetext{
${ }^{68} \mathrm{https://www.facebook.com/tlustalangusta/} \mathrm{(dostęp:} \mathrm{15.06.2020).}$

${ }^{69}$ K.M. Maj, Czas światoodczucia. Imersja jako nowa poetyka odbioru, „Teksty Drugie” 2015, nr 3, s. 372.
} 
jego rozwojowi ${ }^{70}$. Zastosowanie ma tu pojęcie kultury uczestnictwa, która zakłada aktywność odbiorców utożsamiających się z realiami danego świata i osadzajacych w nich własne narracje.

$$
* * *
$$

Opisywane zjawiska wpisują się silnie w tzw. zwrot afektywny. Ryszard Nycz definiuje „kulturę afektu” jako kulturę widziana przez pryzmat jej afektywnego wymiaru oraz taka, która swe specyficzne rysy zawdzięcza zaangażowaniu w afektywne relacje, kształtujące dominujące formy sztuki i literatury. Badacz zwraca uwagę na instytucjonalne strategie organizacji i zarządzania „społeczeństwa doświadczenia” czy „,społeczeństwa przeżycia”71. Tytułowe „afekty w kulturze” rozumie jako „spektrum afektywnych artykulacji pobudzeń oraz reakcji - o charakterze afektów, emocji, uczuć, nastrojów... - manifestujących się w rozmaitych mediach, rodzajach, gatunkach kultury, a sztuki i literatury w szczególności"72. Dzieła odwołujące się do zmysłu dotyku wydają się mocno wpisywać w tę definicję, gdyż nie tylko odwołuja się do intelektualnych i estetycznych kompetencji odbiorcy, lecz także poruszaja jego struktury odczuwania - i to na poziomie zmysłowym, jak i właśnie afektywnym.

Jak zatem widać, współczesna humanistyka, w tym zwłaszcza estetyka, mocno podważa wcześniejsze podziały, kładąc akcent na wielozmysłowy odbiór literatury, sztuki, teatru, działań performatywnych. Niezmiernie istotne sa tu kwestie odbiorcy i oddziaływania na jego zmysły. Coraz częściej w swoich doświadczeniach odbiorczych natrafiamy na dzieła - literackie, plastyczne, teatralne, filmowe, performatywne - tak mocno angażujące i przekraczające definicje tego, co do tej pory leżało w zakresie kompetencji czytelnika i widza, że zostajemy usytuowani na granicy swoich zdolności percepcyjnych i możliwości akceptacji stopnia przekraczania granicy między dziełem a odbiorca. Te przekroczenia są szczególnie widoczne w przywołanych tu przykładach. Niejednorodność, wielopoziomowość, polifoniczność przekazu artystycznego stawiaja odbiorcy coraz bardziej skomplikowane wyzwania. Coraz częściej możemy nie tylko zobaczyć czy wysłyszeć dzieło, lecz także go dotknąć, posmakować, powąchać. Zwłaszcza na poziomie dotykowym sa to ciekawe doznania - tytułowych chropowatości i szorstkości bądź, w opozycji do nich, gładkości. Niejednokrotnie twórcy w swoich dzia-

${ }^{70}$ Zob. ibidem, s. 382.

${ }^{71}$ R. Nycz, Wstẹp. Humanistyka wczoraj i dziś (w wielkim skrócie i nie bez uproszczeń), [w:] Kultura afektu - afekty w kulturze. Humanistyka po zwrocie afektywnym, red. R. Nycz, A. Łebkowska, A. Dauksza, seria Nowa Humanistyka, t. XIX, Warszawa 2015, s. 20.

${ }^{72}$ Ibidem, s. 21. 
łaniach odwołuja się do zjawiska synestezji, które polega na kojarzeniu ze sobą wrażeń pochodzących od różnych zmysłów, np. dźwięków z kolorami, zapachów ze smakami itp. To zjawisko jest częste zarówno w języku potocznym (np. „chropowaty głos”, „ciepły kolor”, „słodki zapach”), jak i w języku literackim (np. poezja Charles'a Baudelaire’a i Artura Rimbauda, twórczość Mirona Białoszewskiego $)^{73}$. W odbiorze sztuki haptycznej czy nastawionych na wielozmysłową aktywność ekspozycji, performansów i spektakli uruchamia się swoista dramaturgia - zaplanowana przez twórcę, wpisana przez niego w dzieło, ale ,aktywowana” dopiero przez odbiorcę traktowanego jako współuczestnika.

\section{BIBLIOGRAFIA}

BIBLIOGRAFIA PODMIOTOWA

777 online, Teatr Usta Usta Republika, spektakl online w aplikacji Zoom, premiera: 16.10.2020, reżyseria: W. Wiński, scenariusz: E. Kaczmarek, K. Macejko, W. Wiński, http://www.ustausta.pl/777-online/ (dostęp: 20.04.2021).

Ambasada 2.0, Teatr Usta Usta Republika, spektakl online w aplikacji Zoom, premiera: 22-24.05.2020, reżyseria: W. Wiński, scenariusz: E. Kaczmarek, K. Macejko, W. Wiński, http://www.ustausta.pl/ambasada-2/ (dostęp: 20.04.2021).

Brama Poznania, https://bramapoznania.pl/oferta-dla-rodzin-z-dziecmi (dostęp: 23.04.2021).

Centrum Nauki Kopernik, https://www.kopernik.org.pl/wydarzenia (dostęp: 23.04.2021).

Dotknać obrazu - Malczewski, Szymborska, Antoniszczak, Muzeum UJ Collegium Maius, 14.10 - 6.12.2013, http://www.dotknijkultury.pl/pl/poprzednie-edycje/2013/ wydarzenia/wystawa-dotknac-obrazu (dostęp: 7.07.2020).

Film dokumentalny: Marina Abramović: Artystka obecna / Marina Abramović: The Artist Is Present, USA 2012 / 106', reżyseria: M. Akers, J. Dupre.

https://muzeumkrakowa.pl/muzeum-bez-barier (dostęp: 20.04.2021).

https://objectlessons.space/posts/2019/sissel-tolaas (dostęp: 10.04.2021). https://sensorymaps.com/?projects=smellwalking-practices-and-influences (dostęp: 10.04.2021). https://sztukawciemno.pl/ (dostęp: 20.04.2021).

https://sztukawciemno.pl/o-projekcie/ (dostęp: 20.04.2021).

Multimedialne Muzeum, https://multimedialnemuzeum.pl/ (dostęp: 23.04.2021).

Muzeum Bajek, Baśni i Opowieści MuBaBaO, https://www.facebook.com/Muzeum-Bajek-Ba\%C5\%9Bni-i-Opowie\%C5\%9Bci-Storyteller-Museum-128032343954199; http:// mubabao.pl/ (dostęp: 23.04.2021).

Muzeum Krakowa, https://muzeumkrakowa.pl/cykle/program-edukacyjny-towarzyszacy-wystawie-w-chocholim-tancu (dostęp: 23.04.2021).

Muzeum Powstania Warszawskiego, https://www.1944.pl/artykul/tajne-komplety-czyli-zwiedzaj-muzeum-inaczej-ni,5114.html (dostęp: 23.04.2021).

${ }^{73}$ https://encyklopedia.pwn.pl/haslo/synestezja;3982085.html (dostęp: 25.04.2021). 
Nie mów nikomu, scenariusz i reżyseria: A. Ziajski, prapremiera: 25.11.2016, Centrum Rezydencji Teatralnej Scena Robocza.

Spójrz na mnie, reżyseria i scenariusz (na podstawie historii bohaterów): A. Ziajski, prapremiera: 23.02.2018, Teatr Ślasski im. Stanisława Wyspiańskiego w Katowicach, premiera poznańska: w ramach cyklu Teatr Powszechny w CK Zamek.

Wystawa (Nie) Dotykaj! Haptyczne aspekty sztuki polskiej po 1945 roku prezentowana w Centrum Sztuki Współczesnej w Toruniu, 11.04 - 17.05.2015, https://csw.torun. $\mathrm{pl} /$ sztuka/wystawy/wystawa-nwystawa-nie-dotykaj-haptyczne-aspekty-sztuki-polskiej-po-1945-rokuie-dotykaj-haptyczne-aspekty-sztuki-polskiej-po-1945-roku-4090/ (dostęp: 7.07.2020).

Wystawa To czuć! Projektowanie dla zmystów, 23.03.2017, Galeria R+ w Szczecinie, https://www.facebook.com/pg/galeriarplus/photos/ (dostęp: 10.04.2021).

Zamek w Kórniku, https://kornik.travel/pl/obiekty/zwiedzanie/zamek=-w-korniku?gclidCj0KCQjw9_mDBhCGARIsAN3PaFPpwAVNuWd0HkhoutucM8fSsYaBxs8vW3p5 AsmInyRsLX2purAgLHQaAugTEALw_wcB (dostęp: 20.04.2021).

BIBLIOGRAFIA PRZEDMIOTOWA

Arystoteles, O duszy, przeł. P. Siwek, Warszawa 1992.

Aschenbrenner K., Jak możliwa jest sztuka?, przeł. M. Gołaszewska, [w:] Eseje o pięknie. Problemy estetyki i teorii sztuki, red. K. Wilkoszewska, Warszawa-Kraków 1988, [także w:] Eidos sztuki, red. M. Gołaszewska, Kraków 1988.

Auslander Ph., Na żywo czy..., przeł. M. Borowski, M. Sugiera, „Didaskalia. Gazeta Teatralna” 2012, nr 107.

Bal M., Wędrujace pojęcia w naukach humanistycznych. Krótki przewodnik, przeł. M. Bucholc, Warszawa 2012.

Bałus W., Dotykanie wzrokiem. O pojęciu haptyczności w klasycznej nauce o sztuce, „Konteksty” 2019, nr 4.

Baumgarten A.G., Metafizyka, przeł. i oprac. J. Surzyn, seria Biblioteka Europejska, Kęty 2012.

Bak S., Dotyk w performansie, [w:] W kulturze dotyku? Dotyk i jego reprezentacje $w$ tekstach kultury, red. A. Łebkowska, Ł. Wróblewski, P. Badysiak, Kraków 2016.

Człowiek posiada więcej ni̇̇ 5 zmystów, 16.06.2016, https://joemonster.org/art/36446 (dostęp: 3.08.2020), źródło anglojęzyczne: D. Hiskey, Humans have a lot more than five senses, 16.07.2010, http://www.todayifoundout.com/index.php/2010/07/humans-have-a-lot-more-than-five-senses/ (dostęp: 3.08.2020).

Encyklopedia PWN, https://encyklopedia.pwn.pl/haslo/muzeum;3944738.html (dostęp: 23.04.2021).

Encyklopedia PWN, https://encyklopedia.pwn.pl/haslo/synestezja;3982085.html (dostęp: 25.04.2021).

Figzał-Janikowska M., Sceny widzialności, 21.03.2018, https://teatralny.pl/recenzje/ sfery-widzialnosci,2313.html (dostęp: 22.04.2021).

Fischer-Lichte E., Estetyka performatywności, przeł. M. Borowski, M. Sugiera, Kraków 2008.

Folga-Januszewska D., Muzeum: definicja i pojęcie. Czym jest muzeum dzisiaj?, „Muzealnictwo" 2008, nr 49.

253 Szorstki i chropowaty dotyk - o dramaturgii zmysłów 
Ghirardo D., Architektura po modernizmie, Torun 1999.

Gtusza, reż. A. Goc, „Tygodnik Powszechny” 22.08.2016, https://www.tygodnikpowszechny.pl/glusza-35169 (dostęp: 21.04.2021).

Gołaszewska M., Estetyka pięciu zmystów, Warszawa-Kraków 1997.

Hegel G.W.F., Wyktady o estetyce, t. 1, przeł. A. Landman, J. Grabowski, Biblioteka Klasyków Filozofii, Warszawa 1964.

Herbert Z., Podróż, [w:] idem, Elegia na odejście, Wrocław 1993.

http://www.scenarobocza.pl/spektakl/1600-nie-mow-nikomu/ (dostęp: 21.04.2021).

http://www.tlustalangusta.pl/ambasada (dostęp: 18.05.2020).

https://www.facebook.com/photo.php?fbid=3462480057115219\&set=a. 19770 7623592495\&type=3\&theater (dostęp: 15.06.2020).

https://www.facebook.com/tlustalangusta/ (dostęp: 15.06.2020).

Inny słownik języka polskiego, t. I: A...Ó, red. M. Bańko, Wydawnictwo Naukowe PWN, Warszawa 2000.

Inny słownik języka polskiego, t. II: P...Ż, red. M. Bańko, Wydawnictwo Naukowe PWN, Warszawa 2000.

Koton-Czarnecka M., Zmysty zwierzqt sq niesamowite. Jak postrzegajq świat?, „National Geographic Polska" 25.02.2020, https://www.national-geographic.pl/artykul/ zmyslowa-ostrosc (dostęp: 8.03.2020).

Kozak P., Wychować Boga. Estetyka antropologiczna Alexandra Gottlieba Baumgartena na tle myśli niemieckiej pierwszej połowy XVIII wieku, Warszawa 2013.

Kubikowski T., Teatr w sieci, [w:] Kultura i sztuka u progu XXI wieku, red. S. Krzemień-Ojak, Białystok 1997.

Maj K.M., Czas światoodczucia. Imersja jako nowa poetyka odbioru, „Teksty Drugie” $2015, \mathrm{nr} 3$.

Mączyńska-Frydryszek A., Jaskólska-Klaus M., Maruszewski T., Psychofizjologia widzenia, red. R. Bartel, Poznań 2001.

Nycz R., Wstęp. Humanistyka wczoraj i dziś (w wielkim skrócie i nie bez uproszczeń), [w:] Kultura afektu-afekty w kulturze. Humanistyka po zwrocie afektywnym, red. R. Nycz, A. Łebkowska, A. Dauksza, seria Nowa Humanistyka, t. XIX, Warszawa 2015.

Piotrowski P., Muzeum krytyczne, Poznań 2011.

Podgórski M., Ucieczka od wizualności i jej społeczne konsekwencje. Fenomen estetyki haptycznej, Poznań 2011.

Popczyk M., Estetyczne przestrzenie ekspozycji muzealnych. Artefakty przyrody i dzieła sztuki, Kraków 2008.

Prajzner K., Tekst jako świat i gra. Modele narracyjności w kulturze wspótczesnej, Łódź 2009, s. 26.

Ripa C., Ikonologia, Kraków 2013.

Rivière G.H., La muséologie selon, Paris 1989.

Rostkowska A., Haptyczne dzieło sztuki, [w:] Materia sztuki, red. M. Ostrowicki, Kraków 2010.

Shusterman R., Estetyka pragmatyczna. Żywe piękno i refleksja nad sztuka, red. nauk. A. Chmielewski, przeł. A. Chmielewski i in., Wrocław 1998.

Stownik języka polskiego PWN, https://sjp.pwn.pl/sjp/chropawy;2448697.html (dostęp: 23.05.2020). 
Stownik języka polskiego PWN, https://sjp.pwn.pl/sjp/immersja;2561260 (dostęp: 20.03.2021).

Stownik języka polskiego PWN, https://sjp.pwn.pl/slowniki/szorstki.html (dostęp: 23.05.2020).

Stownik synonimów, https://antonimy.net/antonim/chropowaty (dostęp: 23.05.2020).

Stownik synonimów, https://synonim.net/synonim/szorstki (dostęp: 23.05.2020).

Smolińska M., (Nie) dotykaj! Haptyczne aspekty sztuki polskiej po 1945 roku, https:// csw.torun.pl/sztuka/wystawy/wystawa-nwystawa-nie-dotykaj-haptyczne-aspekty-sztuki-polskiej-po-1945-rokuie-dotykaj-haptyczne-aspekty-sztuki-polskiej-po-1945-roku-4090/ (dostęp: 20.04.2021).

Smolińska M., Wprowadzenie, [w:] eadem, Haptyczność poszerzona. Zmyst dotyku w sztuce polskiej drugiej połowy XX i poczatku XXI wieku, Kraków 2020.

Stefanik M., Kamel M., Muzea i wystawy interaktywne w Polsce - wspótczesna atrakcja turystyczna, „Turystyka Kulturowa” 2013, nr 8.

Sugiera M., Nażywość, [w:] Performatyka: terytoria, red. E. Bal, D. Kosiński, Kraków 2017.

Tatarkiewicz W., Dzieje sześciu pojęć: sztuka, piękno, forma, twórczość, odtwórczość, przeżycie estetyczne, red. E. Nowakowska, Warszawa 1975.

Tkaczyk K., Johann Gottfried Herder. Sensualistyczny bunt wobec klasycznej estetyki, [w:] W kulturze dotyku? Dotyk i jego reprezentacje w tekstach kultury, red. A. Łebkowska, Ł. Wróblewski, P. Badysiak, Kraków 2016.

Tyszka J., Zza szyby po wegiersku, 21.12.2016, https://teatralny.pl/recenzje/zza-szyby-po-wegiersku,1802.html (dostęp: 21.04.2021).

Monika Błaszczak - adiunkt w Zakładzie Estetyki Literackiej Instytutu Filologii Polskiej na Uniwersytecie im. Adama Mickiewicza w Poznaniu. Literaturoznawca, teatrolog i kulturoznawca. Jej zainteresowania badawcze obejmuja: estetykę literacka i performatywna, współczesny i najnowszy dramat i teatr, estetykę odbioru i strategie odbiorcze we współczesnym teatrze i sztukach performatywnych, kategorie estetyczne w ujęciu interdyscyplinarnym i transdyscyplinarnym, łączącym perspektywy: literaturoznawcza, kulturoznawcza i teatrologiczna oraz praktyczne aspekty kultury, takie jak: zarządzanie w kulturze, sztuka autoprezentacji, kuratorstwo kulturalne. ORCID: 0000-0002-3942-8026. Adres e-mail: <monika.blaszczak@amu.edu.pl>.

Monika Blaszczak - PhD, lecturer in the Department of Literary Aesthetics of the Institute of Polish Philology at Adam Mickiewicz University in Poznan. Literary scholar, theater and culture expert. Her research interests include literary and performative aesthetics, contemporary and recent drama and theater, the aesthetics of reception and reception strategies in contemporary theater and performing arts, aesthetic categories from an interdisciplinary and transdisciplinary perspective, combining literary, cultural and theater perspectives, as well as practical aspects of culture, such as management in culture, the art of self-presentation, cultural curatorial. ORCID: 0000-0002-3942-8026. E-mail address: <monika.blaszczak@amu.edu.pl>. 
